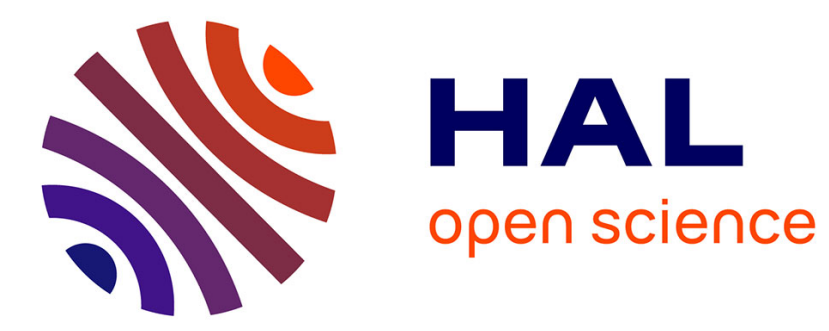

\title{
Occurrence, origin, and toxicity of disinfection byproducts in chlorinated swimming pools: An overview
}

Tarek Manasfi, Bruno Coulomb, Jean Luc Boudenne

\section{To cite this version:}

Tarek Manasfi, Bruno Coulomb, Jean Luc Boudenne. Occurrence, origin, and toxicity of disinfection byproducts in chlorinated swimming pools: An overview. International Journal of Hygiene and Environmental Health, 2017, 220 (3), pp.591-603. 10.1016/j.ijheh.2017.01.005 . hal-02282203

\section{HAL Id: hal-02282203 https://hal.science/hal-02282203}

Submitted on 9 Sep 2019

HAL is a multi-disciplinary open access archive for the deposit and dissemination of scientific research documents, whether they are published or not. The documents may come from teaching and research institutions in France or abroad, or from public or private research centers.
L'archive ouverte pluridisciplinaire HAL, est destinée au dépôt et à la diffusion de documents scientifiques de niveau recherche, publiés ou non, émanant des établissements d'enseignement et de recherche français ou étrangers, des laboratoires publics ou privés. 


\title{
Occurrence, origin and toxicity of disinfection byproducts in chlorinated swimming pools: An overview
}

\author{
Tarek Manasfi ${ }^{\mathrm{a}}$, Bruno Coulomb ${ }^{\mathrm{a}}$, Jean-Luc Boudenne ${ }^{\mathrm{a}, *}$ \\ ${ }^{a}$ Aix Marseille Université, CNRS, LCE UMR 7376, 13331 Marseille, France \\ (E-mail: tarek.manasfi@univ-amu.fr; bruno.coulomb@univ-amu.fr; jean-luc.boudenne@univ-amu.fr) \\ *Corresponding Author: Jean-Luc Boudenne; 3 Place Victor Hugo-Case 29, 13331 Marseille, \\ France; Phone: +33413551031; Email: jean-luc.boudenne@univ-amu.fr
}

\begin{abstract}
Disinfection treatments are critical to conserve the microbiological quality of swimming pool water and to prevent water-borne infections. The formation of disinfection byproducts (DBPs) in swimming pools is an undesirable consequence resulting from reactions of disinfectants (e.g. chlorine) with organic and inorganic matter present in pool water, mainly brought by bathers. A considerable body of occurrence studies has identified several classes of DBPs in swimming pools with more than 100 compounds detected, mainly in chlorinated freshwater pools. Trihalomethanes (THMs), haloacetic acids (HAAs), haloacetaldehydes (HALs) are among the major DBPs in swimming pools. Other DBPs such as haloacetonitriles (HAN), haloamines, nitrosamines, and halobenzoquinones have also been detected. Researchers have been interested in identifying the precursors responsible for the formation of DBPs. In swimming pools, anthropogenic organic loads brought by swimmers increase the complexity of pool water chemistry. When human inputs (e.g. sweat, urine, hair, skin and personal care products) containing very diverse organic compounds are introduced to pools by swimmers, they react with chlorine resulting in the formation of complex mixtures of DBPs. The overwhelming majority of the total organic halide (TOX) content is still unknown in swimming pools. Exposure of swimmers to DBPs can take place through multiple routes, depending on the chemical properties of each DBP. Toxicological studies have shown that swimming pool water can be mutagenic with different potencies reported in different studies. Many DBPs have been shown to be genotoxic
\end{abstract}


and carcinogenic. DBPs were also shown to induce reproductive and neurotoxic adverse effects in animal studies. Epidemiologic studies in humans have shown that exposure to DBPs increases the risk of respiratory adverse effects and bladder cancer. Association between DBPs and other health effects are still inconclusive. Data gathered in the present review (occurrence, toxicity, and toxicological reference values) could be used in conducting chemical risk assessment studies in swimming pools.

\section{Introduction}

Disinfection of drinking water was one of the major public health advances of the twentieth century. The adoption of water chlorination as a standard treatment technique caused a large drop in mortality from infectious disease around the world (Boorman, 1999). The efficiency of chlorination in conserving the quality of drinking water from microbiological deterioration has contributed to the extrapolation of its application to include swimming pools and recreational water venues (WHO, 2006). Disinfection of swimming pool water is essential to kill pathogenic microorganisms and prevent outbreaks of infectious diseases (ANSES, 2012). Chlorination represents the most commonly used disinfection treatment in swimming pools (Lakind et al., 2010). Chlorine can be added in the form of compressed chlorine gas, sodium hypochlorite solution $(\mathrm{NaOCl})$, or solid calcium hypochlorite $\left(\mathrm{Ca}(\mathrm{OCl})_{2}\right)$. Alternative disinfectants include other chlorine-based disinfectants (e.g. chlorine dioxide, stabilized chlorine), chloramines, and ozone. As in drinking water, disinfection of swimming pool water leads to the undesirable formation of disinfection byproducts (DBPs). Evidence from toxicological and epidemiological studies about adverse health effects for DBPs have raised concerns about the chemical safety of swimming pool waters. The first studies investigating the occurrence of DBPs in swimming pools date back to 1980 (Beech et al., 1980; Weil et al., 1980). Since then, many studies have been performed to examine the occurrence of DBPs in pools in different countries (Aggazzotti and Predieri, 1986; Chu and Nieuwenhuijsen, 2002; Judd and Jeffrey, 1995; Kim et al., 2002). Today, after more than 35 years of research, more than 100 DBP have been detected in swimming pools (Chowdhury et al., 2014; Daiber et al., 2016; Richardson et al., 2010; Teo et al., 2015). The formation of DBPs in swimming pool waters is attributed to precursors that can be derived from the filling water as well as from pool users. Human inputs into swimming pools are diverse and include constituents of urine, sweat, rhino-pharyngeal secretions, skin particles, skin lipids 
(sebum), hair, cosmetics, sunscreens and other personal care products (Keuten et al., 2012, 2014; Kim et al., 2002; Lakind et al., 2010; Richardson et al., 2010; Weisel et al., 2009). Chlorine, mainly in the form of hypochlorous acid and hypochlorite ions, reacts with these organic compounds resulting in the formation of complex mixtures of DBPs. Many classes of DBPs including haloamines, trihalomethanes (THMs), haloacetic acids (HAAs), haloacetonitriles (HANs), halodiacids, haloacetaldehydes (HALs), haloketones (HKs), haloaldehydes, haloamides, halophenols, halobenzoquinones and $N$-nitrosamines, have been identified in swimming pools (Chowdhury et al., 2014; Richardson et al., 2010; Teo et al., 2015; Wang et al., 2013; Zwiener et al., 2007). However, the continuous inputs of organic loads by swimmers results in the formation of complex mixture of DBPs that have not been identified yet. In drinking water, more than $50 \%$ of the halogenated DBP material formed during chlorination are still not accounted for (Krasner et al., 2006; Richardson and Postigo, 2011; Weinberg et al., 2002). Taking into consideration the complexity of anthropogenic inputs, the fraction of unidentified DBPs in swimming pools is even higher (Kim et al., 2002; Lakind et al., 2010; Manasfi et al., 2017b). The following sections present an overview of occurrence data for DBPs in swimming pools, the precursors that have been demonstrated to generate DBPs, and finally the toxicological and human health effects related to the exposure to DBPs.

\section{Occurrence of DBPs in Swimming Pools}

In the recent years, many studies have investigated the occurrence of DBPs in swimming pools. The levels and nature of DBPs in swimming pools depend on several factors including the type of disinfectant, characteristics of the pool, pool users' hygiene (Zwiener et al., 2007), use of pools (competition, relaxation, recreational activities) (Weng et al., 2011; Keuten et al., 2014), and nature of water used to fill the pools whether it is tap water, seawater or even thermal water (ANSES, 2013). Most of the studies analyzing the occurrence of DBPs investigated pools that were filled with municipal (tap) water and treated with chlorine (Teo et al., 2015). Very few studies dealt with pools fed with seawater or with bromide-rich water (Huang et al., 2008; Parinet et al., 2012; Manasfi et al., 2016; Font-Ribera, 2016) or with pools treated with bromine for disinfection (Lee et al., 2010; Hoffmann, M., 2015; Chowdhury et al., 2016). Two recent papers have reviewed the major disinfection by-products that have been commonly reported in chlorinated and brominated swimming pools (Chowdhury et al., 2014; Teo et al., 2015). The 
detected DBPs included haloamines, THMs, HAAs, haloaldehydes, halonitriles, haloketones (HKs), halonitromethanes, haloamides, haloalcohols, haloacids and other halogenated and nonhalogenated DBPs (Chowdhury et al., 2014).

\section{Haloamines}

In terms of occurrence levels, chloramines (or bromamines in bromide-rich waters) are the disinfection by-products detected at the highest levels amongst DBPs, with monochloramine $\left(\mathrm{NH}_{2} \mathrm{Cl}\right.$ ) mainly found in water (up to $1180 \mu \mathrm{g} \mathrm{L} \mathrm{L}^{-1}$ ), followed by trichloramine $\left(\mathrm{NCl}_{3}\right.$ ) (up to 800 $\mu \mathrm{g} \mathrm{L}^{-1}$ ) and dichloramine $\left(\mathrm{NHCl}_{2}\right.$ ) (up to $650 \mu \mathrm{g} \mathrm{L}^{-1}$ ) (Table 1). Trichloramine, which is four hundred-fold more volatile than its two congeners (Chu et al., 2013), is also found in air with levels strongly inversely correlated to ventilation applied in indoor swimming pools (Lévesque et al., 2015; Gérardin et al., 2015).

Table 1: Occurrence of haloamines in swimming pools around the world

\begin{tabular}{|c|c|c|c|c|c|c|}
\hline \multirow{2}{*}{ Country } & \multirow{2}{*}{$\begin{array}{l}\text { Air }\left(\mu \mathrm{g} \cdot \mathrm{m}^{-3}\right) \\
\mathrm{NCl}_{3}\end{array}$} & \multicolumn{3}{|c|}{ Water $\left(\mu \mathrm{g} \mathrm{L}^{-1}\right)$} & & \multirow{2}{*}{ References } \\
\hline & & $\mathrm{NCl}_{3}$ & $\mathrm{NHCl}_{2}$ & $\mathrm{NH}_{2} \mathrm{Cl}$ & & \\
\hline France & $20-1260$ & \multicolumn{3}{|c|}{$5-1700^{*}$} & indoor & Anses, 2010; Bessonneau et al., 2011 \\
\hline Switzerland & $38-520$ & \multicolumn{3}{|c|}{-} & indoor & Parrat et al., 2012 \\
\hline \multirow[t]{3}{*}{ Québec } & $300-510$ & $102-568$ & $38-206$ & $171-948$ & indoor & Simard et al., 2013; Lévesque et al., 2015 \\
\hline & - & $2.6-280$ & 1.3-137 & $4-430$ & outdoor & Simard et al., 2013 \\
\hline & $80-350$ & $<$ LOD-650 & $<$ LOD-593 & $<$ LOD-450 & indoor & Catto et al., 2012 \\
\hline \multirow[t]{2}{*}{ USA } & - & $<$ LOD-377 & $<$ LOD-147 & $<$ LOD-1180 & indoor & Weaver et al., 2009 \\
\hline & & $100-800 * *$ & $80-180$ & $180-320$ & indoor & Weng et al., 2011 \\
\hline Taïwan & $17-150$ & \multicolumn{3}{|l|}{$100-1650 *$} & indoor & Chu et al., 2013 \\
\hline Sweden & $1-640$ & \multicolumn{3}{|c|}{-} & indoor & Westerlund et al., 2015 \\
\hline Italy & $200-1020$ & \multicolumn{3}{|c|}{-} & indoor & Fantuzzi et al., 2013 \\
\hline \multirow[t]{2}{*}{ Spain } & $170-430$ & $<$ LOD-377 & $<$ LOD-650 & $100-640$ & indoor & Richardson et al., 2010 \\
\hline & $248-858$ & $<$ lod-1600 & $<$ lod-700 & $<$ lod-700 & indoor & Font-Ribera et al., 2016 \\
\hline \multicolumn{7}{|c|}{ *these values represent the sum of inorganic chloramines determined using the DPD method } \\
\hline \multicolumn{7}{|c|}{ ** these high values can be explained because of sampling during a swimming competition } \\
\hline \multicolumn{2}{|c|}{$<L O D$ : below the limit of detection } & & & & & \\
\hline
\end{tabular}

Chloramines are often determined as a global parameter (combined chlorine or total inorganic chloramines) by the use of the colorimetric N,N-diethyl-p-phenylenediamine (DPD). However, only membrane introduction mass spectrometry (MIMS) has demonstrated its performance not only to avoid interferences encountered using the DPD method (due to organic chloramines) (Weaver et al., 2009) but also to discriminate the three inorganic chloramines (Kinani et al., 
2012) and to analyze cyanogen halide compounds, such as cyanogen chloride (CNCl) and cyanogen bromide (CNBr) (Yang and Shang, 2005).

\section{Trihalomethanes (THMs)}

THMs have been detected at high concentrations in swimming pools, representing between 5 to $10 \%$ of total organohalogens as determined by the adsorbable organic halide (AOX) method, with chloroform $\left(\mathrm{CHCl}_{3}\right)$ being the dominant species (Aggazzotti and Predieri, 1986; Beech et al., 1980; Erdinger et al., 2004; Fantuzzi et al., 2001; Lee et al., 2009; Nieuwenhuijsen et al., 2000; Simard et al., 2013; Weaver et al., 2009), or bromoform $\left(\mathrm{CHB}_{\mathrm{r} 3}\right)$ when bromide present in high concentrations or used as disinfectant (Lourencetti et al., 2012; Parinet et al., 2012; Manasfi et al., 2016). THMs also include dichlorobromethane and bromodichloromethane. Table 2 gives an overview of the levels of THMs found in water and air of some swimming pools spread over the world.

Table 2: Occurrence of trihalomethanes (THM) in indoor swimming pools

\begin{tabular}{|c|c|c|c|c|c|c|c|c|c|c|c|}
\hline & & & \multicolumn{4}{|c|}{ Water $\left(\mu \mathrm{g} \cdot \mathrm{L}^{-1}\right)$} & \multicolumn{4}{|c|}{$\operatorname{Air}\left(\mu \mathrm{g} \cdot \mathrm{m}^{-3}\right)$} & \multirow[t]{2}{*}{ References } \\
\hline & & $n$ & $\mathrm{CHCl}_{3}$ & $\mathrm{CHCl}_{2} \mathrm{Br}$ & $\mathrm{CHClBr}_{2}$ & $\mathrm{CHBr}_{3}$ & $\mathrm{CHCl}_{3}$ & $\mathrm{CHCl}_{2} \mathrm{Br}$ & $\mathrm{CHClBr}_{2}$ & $\mathrm{CHBr}_{3}$ & \\
\hline \multirow{10}{*}{$\begin{array}{l}\text { Chlorine- } \\
\text { based } \\
\text { disinfectant }\end{array}$} & Italy & 5 & $6.1-68.4$ & $2-5.3$ & $0.4-5.4$ & $<$ lod & $19-58.6$ & $2.9-13$ & $0.3-6$ & $<$ lod-0.8 & Fantuzzi et al., 2001 \\
\hline & & 1 & $8.5-20$ & $9.4-25$ & $6.7-23$ & 3.1-16 & $18-61$ & $8.2-23$ & $6.4-22$ & $5.9-22$ & Lourencetti et al., 2012 \\
\hline & & 24 & $2.5-122$ & $1.4-18.3$ & $0.2-11.7$ & $<$ lod-3.6 & & & & & Righi et al., 2014 \\
\hline & Korea & 30 & $<$ lod- 45.8 & $<$ lod-7 & $<$ lod & $<$ lod & \multicolumn{4}{|c|}{-} & Lee et al., 2010 \\
\hline & Spain & 1 & $24-61.6$ & 3.8-12.9 & $0.9-4.7$ & $0.2-1.9$ & \multicolumn{4}{|c|}{-} & Font-Ribera et al., 2016 \\
\hline & & 16 & 22.3-217 & $3.6-25.2$ & $0.4-5.3$ & $0.2-2.8$ & \multicolumn{4}{|c|}{-} & Font-Ribera et al., 2010 \\
\hline & & 12 & $8.4-20.8$ & $9.3-26.8$ & $6.5-22.6$ & 3-16.5 & $11.9-61.6$ & 7.5-23.4 & $6.1-26.2$ & $4.4-22.6$ & Richardson et al., 2010 \\
\hline & USA & 11 & $<$ lod-173 & $<$ lod-150 & $<$ lod-54 & $<$ lod-67.9 & \multicolumn{4}{|c|}{-} & Weaver et al., 2009 \\
\hline & Canada & 41 & $6.7-126.5$ & $<$ lod-30.1 & $<$ lod-51.3 & $<$ lod- 45.6 & $20.3-320.4$ & $1.3-154.6$ & $<$ lod-204.8 & $<$ lod-102.8 & Tardif et al., 2016 \\
\hline & & 15 & $12.9-215$ & $<$ lod-23.9 & $<$ lod-27.1 & $<$ lod-19.2 & & & & & Simard et al., 2008 \\
\hline \multirow{7}{*}{$\begin{array}{l}\text { Bromine- } \\
\text { based } \\
\text { disinfectant or } \\
\text { chlorinated } \\
\text { bromide-rich } \\
\text { waters }\end{array}$} & France & 8 & $0.03-0.3$ & $0.05-1.1$ & $13.6-63.6$ & 28-930 & \multicolumn{4}{|c|}{-} & Parinet et al., 2012 \\
\hline & & 3 & $<$ lod & $<$ lod & $1.6-3.9$ & $48.9-62.5$ & \multicolumn{4}{|c|}{-} & Manasfi et al., 2016 \\
\hline & & 3 & $<$ lod & $<$ lod & 2.1-5.5 & 49.7-101.3 & $<$ lod & $<$ lod & $3.6-20.7$ & $21.7-240.1$ & Manasfi et al., 2017b \\
\hline & Italy & 1 & $0.08-0.29$ & $0.23-0.6$ & $2.1-2.6$ & $52-61$ & $1.8-6.9$ & $1.9-4.2$ & $6.4-8.7$ & $55-92$ & Lourencetti et al., 2012 \\
\hline & Spain & 4 & $0.5-2$ & $0.3-2.5$ & $1.2-5.1$ & 78.6-146.6 & \multicolumn{4}{|c|}{-} & Font-Ribera et al., 2010 \\
\hline & & 7 & $0.08-0.3$ & $0.22-0.43$ & $2.1-2.5$ & $52-64$ & $1.7-4.8$ & $1.7-2.8$ & $6.0-7.7$ & $53-77$ & Marco et al., 2015 \\
\hline & $n=$ number & of po & alyzed & - : not dete & hined; $<$ lod & elow the lim & ection & & & & \\
\hline
\end{tabular}

\section{Haloacetics acids (HAAs)}

HAAs have also been detected as predominant DBPs (25 to 30\% of total organohalogens, determined by the AOX method) with dichloroacetic acid (DCAA) and trichloroacetic acid (TCAA) occurring at the highest concentrations in most of the analyzed pools (Cardador and Gallego, 2011; Lee et al., 2010; Sá et al., 2012; Wang et al., 2014; Yeh et al., 2014). Simard et al. 
analyzed 39 outdoor and 15 indoor public pools in Canada and found that HAAs were higher in outdoor pools compared to indoor pools (Simard et al., 2013). In bromide-rich waters, chlorinated HAAs are shifted to their brominated analogues, with tribromoacetic acid (TBAA), chlorodibromoacetic acid (CDBAA) and dichlorobromoacetic acid (DCBAA) mostly found (Parinet et al., 2012; Manasfi et al., 2017b, 2016). HAA concentrations reported in swimming pool water are always higher than those for THMs. This can be explained partially by the higher volatility of THMs as compared to HAAs (Table S1, in supporting information). In addition, the higher formation potential of bather organic loads to form HAAs than THMs and the stability of HAAs towards chlorine and $\mathrm{pH}$ variation tend to favor their accumulation in water (Kanan and Karanfil, 2011; Lakind et al., 2010). Table 3 gives an overview of HAAs detected in chlorinated tap water swimming pools, chlorinated seawater swimming pools, and brominated swimming pools and spas.

Table 3: Occurrence of haloacetic acids (HAA) in swimming pools

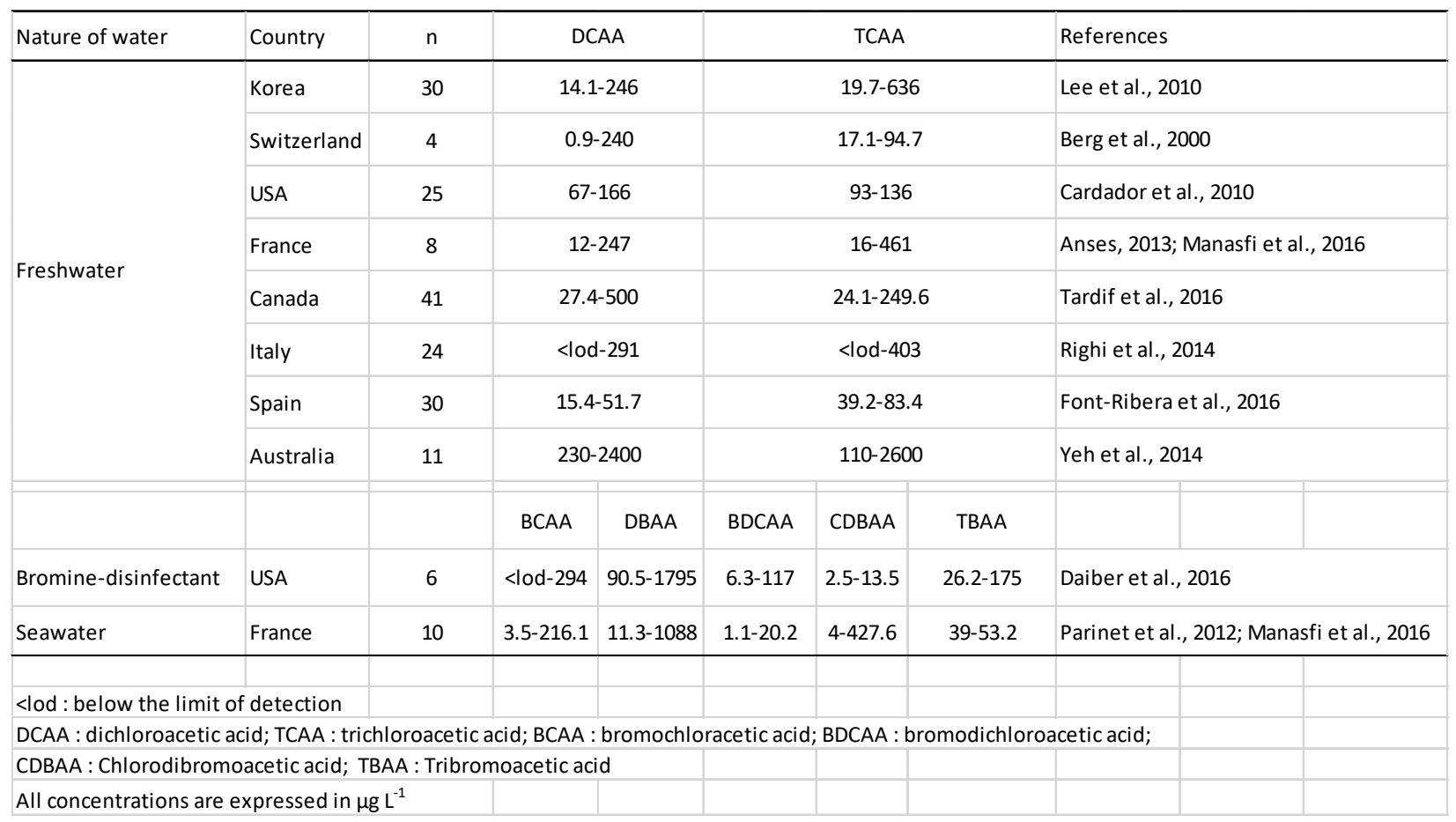


swimming pools at levels varying from 31.8 and up to $497 \mu \mathrm{g} \mathrm{L}^{-1}$ (n=37; mean : $180.3 \mu \mathrm{g} \mathrm{L}^{-1}$;

median: $118.9 \mu$ g.L $\mathrm{L}^{-1}$ ) (Freyfer, 2012), in Korean Swimming pools between 5 and $35 \mu g \mathrm{~L}^{-1}$ (Lee et al., 2010), and in outdoor Australian swimming pools between 19.4 and $23.8 \mu \mathrm{g} \mathrm{L}^{-1}$ (Yeh et al., 2014). In chlorinated bromide-rich water or when bromine is used as disinfectant, bromal hydrate (BH) is the predominant trihaloacetaldehyde (Daiber et al., 2016; Manasfi et al., 2017b, 2016). In a recent study, $\mathrm{BH}$ was detected as one of the degradation byproducts of benzophenone-3, a UV filter commonly used in sunscreens, in chlorinated swimming pools filled with seawater (Manasfi et al., 2015a). BH was detected in seawater swimming pools at low levels (0.35-2.22 $\mu \mathrm{g} \mathrm{L}^{-1}$ ) (Manasfi et al., 2015b), probably due to its increased instability at the slightly basic pH of seawater (8.2-8.6) (Koudjonou and LeBel, 2006).

\section{Haloacetonitriles (HANs)}

The most commonly reported HANs include dichloroacetonitrile (DCAN, $\mathrm{CNCHCl}_{2}$ ), trichloroacetonitrile (TCAN, $\mathrm{CNCCl}_{3}$ ), bromochloroacetonitrile (BCAN, $\mathrm{CNCHBrCl}$ ) and dibromoacetonitrile ( $\left.\mathrm{DBAN}, \mathrm{CNCHBr}_{2}\right)$. HANs are soluble substances, even if lipophilic, which are susceptible to degradation due to hydrolysis reaction or by reaction with the residual chlorine. HANs are purgeable substances, so they are volatile, but they are less volatile than chloroform (Table S1). HANs are also byproducts of degradation of THMs and HAAs in certain conditions (Weaver et al., 2009; Lee et al., 2010). HAN production is directly related to the content of nitrogen compounds (urea, ammonium, creatine, amino acids) (Li and Blatchley, 2007; Weaver et al., 2009; Deiber et al., 2016). DCAN and BCAN are the two compounds mostly encountered in freshwater swimming pools (Tardif et al., 2016). DBAN is the predominant HAN in brominedisinfected swimming pools (Deiber et al., 2016) and in chlorinated seawater pools (Parinet et al., 2012; Manasfi et al., 2017b, 2016). Table 4 presents HAN concentrations reported in swimming pools. 
Table 4: Occurrence of haloacetonitriles (HAN) in swimming pools

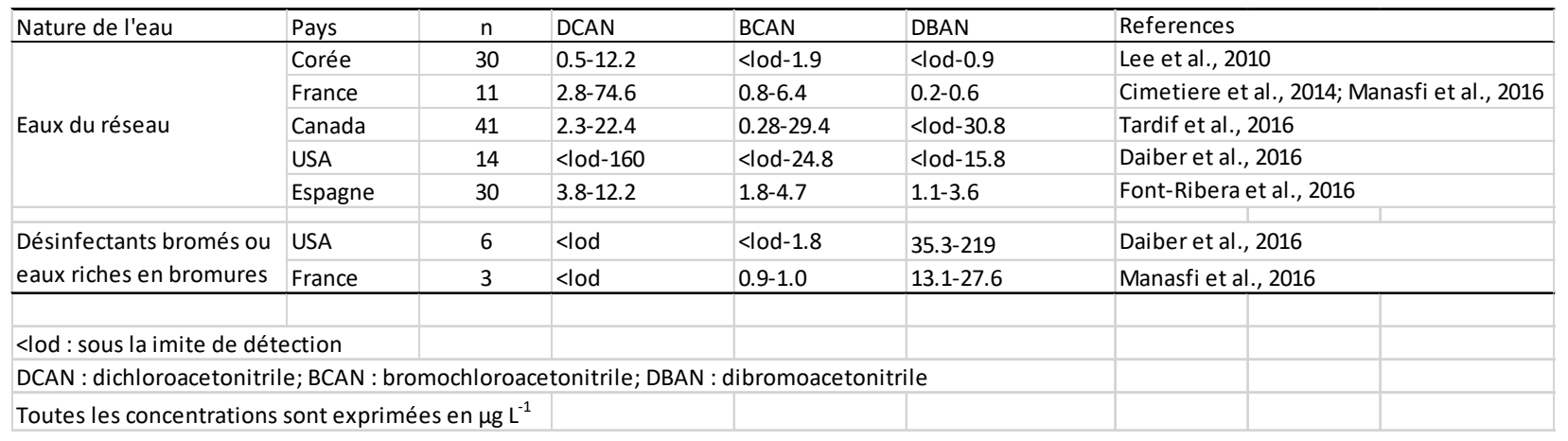

\section{Other (or emerging) DBPs}

DBPs presented above account for the largest components of identified DBPs found in chlorinated swimming pools (by weight), as assessed by comparison of the sum of their concentrations with their adsorbable organic halide (AOX) concentrations (Yeh et al., 2014). However, few recent studies have revealed the presence of other compounds that could have a health impact, even at the ng $\mathrm{L}^{-1}$ level. Among these emerging compounds, nitrogenous DBPs are of the greatest concern for human health because of their higher genotoxicity, cytotoxicity, and carcinogenicity (Richardson et al., 2010). Halonitromethanes (HNMs), including trichloronitromethane (TCNM or chloropicrin or nitrochloroform), bromonitromethane (BNM), bromochloronitromethane (BCNM) and dibromonitromethane (DBNM), have been detected in

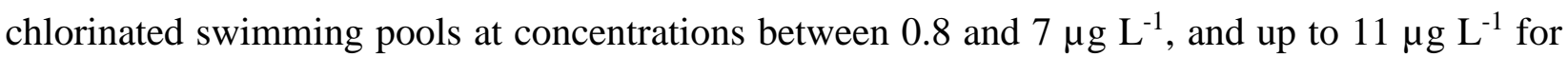
BCNM (Kanan, 2010). Recently, TCNM was detected at levels varying between 0.07 and 1.43 $\mu g \mathrm{~L}^{-1}$ (Tardif et al., 2016). Among nitrosamines, $N$-nitrosodimethylamine (NDMA) has been reported in few studies at levels varying from $32 \mathrm{ng} \mathrm{L}^{-1}$ (Walse and Micth, 2008) to $210 \mathrm{ng} \mathrm{L}^{-1}$ (Kim and Han, 2011) and up to 310 ng L- ${ }^{1}$ in a hot tub (Walse and Mitch, 2008). NDMA has also been reported in Canada by Tardif et al. (2016) with levels varying between 2.4 and $25.4 \mathrm{ng} \mathrm{L}^{-1}$. This compound may result either from the reaction between dichloramine and dimethylamine (present in urea and sweat), or by the reaction of $\mathrm{N}_{2} \mathrm{O}_{4}$ (resulting from the reaction of chlorine and nitrites) with dimethylamine (Walse and Mitch, 2008). Other nitrosamines ( $N$ nitrosodiethylamine (NDEA), $N$-nitrosomorpholine (NMor), $N$-nitrosopyrrolidine (NPyr), $N$ nitrosopiperidine (NPip) and $N$-nitrosodibutylamine (NDBA) have also been reported but at very lower levels (Teo et al., 2015). Cyanogen compounds ( $\mathrm{CNCl}$ and $\mathrm{CNBr}$ ) are also formed in 
swimming pools, due to the reaction of nitrogenous compounds of body fluids with chlorine, and from the reaction of chloramines with ammonium (Lian et al., 2014). The reported levels ranged between 1 to $21 \mu \mathrm{g} \mathrm{L}^{-1}$ for $\mathrm{CNCl}$ and 1 to $25 \mu \mathrm{g} \mathrm{L}-1$ (Weaver et al., 2009). Dichloromethylamine (DCMA, $\mathrm{CH}_{3} \mathrm{NCl}_{2}$ ) was detected as a byproduct of creatinine chlorination ( $\mathrm{Li}$ and Blatchley, 2007). DCMA was found in hot tub waters in USA by Weaver et al. (2009) at concentrations between 0.05 and $50.98 \mu \mathrm{g} \mathrm{L}^{-1}$ and in atmosphere of indoor pools in France at concentrations varying between 16 and $70 \mu g \cdot \mathrm{m}^{-3}$ (Cimetiere et De Laat, 2009). Recently, several halobenzoquinones were detected in chlorinated swimming pool waters (Wang et al., 2013). Authors conducted chlorination experiments that showed that halobenzoquinones were formed from the chlorination of sunscreens and lotions. Very recently, an extensive study analyzed the occurrence of DBPs and the mutagenicity of water in pools and spas treated with chlorine, bromine or ozone (Daiber et al., 2016). Authors identified more than 100 DBPs including a new class of DBPs, bromoimidazoles. Occurrence data for these emerging DBPs in seawater pools are very limited.

\section{Formation of DBPs in Swimming Pools}

\section{Reactivity of chlorine}

Chlorine is used in the form of gaseous chlorine, liquid sodium hypochlorite ( $\mathrm{NaOCl})$, or solid calcium hypochlorite $\left(\mathrm{Ca}(\mathrm{OCl})_{2}\right)$. The different forms of chlorine, when applied to water, generate hypochlorous acid ( $\mathrm{HOCl})$ which is a weak acid with a $\mathrm{pK}_{\mathrm{a}}$ of approximately 7.5 at 25 ${ }^{\circ} \mathrm{C}$. The $\mathrm{pH}$ of water affects the dominating chlorine species such that $\mathrm{HOCl}$ dominates at $\mathrm{pH}$ below 7.5, while hypochlorite ions $\left(\mathrm{OCl}^{-}\right)$dominate at $\mathrm{pH}$ above 7.5. Of the two species, $\mathrm{HOCl}$ is the stronger oxidant (WHO, 2000). The reactivity of chlorine with inorganic compounds (e.g. ammonia, halides $\mathrm{Br}^{-}$and $\mathrm{I}^{-}, \mathrm{Fe}(\mathrm{II}), \mathrm{As}(\mathrm{III})$, Sulfates $\mathrm{SO}_{4}{ }^{2-}, \mathrm{CN}^{-}, \mathrm{NO}_{2}{ }^{-}$) usually results from an initial electrophilic attack. Reactions of chlorine with organic compounds may involve oxidation, addition, and electrophilic substitution reactions as possible pathways. However, only electrophilic attacks are significant from a kinetic point of view (Deborde and von Gunten, 2008). In water containing bromide ions, chlorination results in the formation of hypobromous acid, which is a weak acid $\left(\mathrm{pK}_{\mathrm{a}}=8.7\right)$. The speciation of bromine between hypobromous acid and hypobromite ions depends on the $\mathrm{pH}$ of water. As a halogenating agent, bromine is usually more reactive than chlorine especially with phenolic compounds leading to the formation of 
brominated products (Acero et al., 2005; Gallard et al., 2003; Hua et al., 2006). Thus, bromide levels, $\mathrm{pH}$, and other factors (e.g. temperature, organic content) can affect the composition and levels of DBPs in chlorinated swimming pools (Teo et al., 2015; WHO, 2000)

\section{Precursors of DBPs in swimming pools}

\section{Natural organic matter}

Natural organic matter (NOM) was the first known precursors to be accounted for the formation of DBPs in chlorinated drinking waters (Bellar et al., 1974; Rook, 1974). Similar to drinking water, DBPs can be formed from reactions of chlorine with NOM present in the filling water of swimming pools (Chowdhury et al., 2014; Kanan and Karanfil, 2011). These reactions result in the formation of THMs, HAAs, HANs, HKs, and halofuranones (Urbansky and Magnuson, 2002). Kanan and Karanfil (2011) conducted a comparative formation potential study and showed that NOM in chlorinated swimming pools formed more THMs than HAAs.

\section{Body fluids released by swimmers}

Human body fluids are believed to be major precursors for the formation of DBPs in swimming pools (Kim et al., 2002). It has been estimated that a swimmer releases approximately $25-77 \mathrm{~mL}$ in average (De Laat et al., 2011; Weng et al., 2012). In addition, Seux (1985) estimated that every swimmer introduces into the pool 100 to $1000 \mathrm{ml} / \mathrm{h}$ of sweat depending on the physical activity. Nitrogen-containing DBPs are generally attributed to nitrogenous organic precursors present in human body fluids (mainly urine and sweat) such as uric acid, urea, creatinine, L-arginine, Lhistidine, glycine, and ammonia (Lian et al., 2014; Weng et al., 2012). The reaction pathways leading to the formation of DBPs from the chlorination of these organic compounds have been previously identified (Blatchley and Cheng, 2010; De Laat et al., 2011; Freuze et al., 2005; Hureiki et al., 1994; Jafvert and Valentine, 1992; Joo and Mitch, 2007; Li and Blatchley, 2007; $\mathrm{Na}$ and Olson, 2006). Trichloramine has been identified as a byproduct of chlorination of organic nitrogenous compounds present in body fluids ( $\mathrm{Li}$ and Blatchley, 2007; Lian et al., 2014). The highly toxic cyanogen chloride $(\mathrm{CNCl})$ has been identified as a byproduct of chlorination of glycine (Lee et al., 2006; Li and Blatchley, 2007) and uric acid (Lian et al., 2014). L-Histidine was found to act as precursor for the formation of dichloroacetonitrile (DCAN) and slightly to the 
formation of CNCl. Besides nitrogenous DBPs, reactions of chlorine with human body fluids also generates non-nitrogenous DBPs including HAAs, THMs, THA, and HK (Kim et al., 2002). Formation potential studies conducted on body fluid analogs showed their tendency to form more HAAs than THMs (Kanan and Karanfil, 2011).

\section{Particles released by swimmers}

The potential of particles (e.g. skin cells, hair, and microorganisms) to form DBPs in swimming pools has been first demonstrated by Kim et al. (2002). Recently, Hansen et al. (2012b) examined the potential of particles captured by filters in swimming pools to form DBPs. The particles were collected from hot tubs and treated with chlorine in laboratory-controlled experiments. The formation of DBPs from human particles was found to be higher than that reported from other precursors including body fluid analogues (BFA) and natural organic matter (Table S2), probably due to high contents of nitrogenous precursors present in human particles. However, the formation of DBPs from particles released by bathers still merit further research since particles studied in previous investigations have not been fully characterized and discriminated. In the previously conducted studies, there has been no separation of skin and hair particles from microorganisms which themselves have been already shown to acts as precursors for DBPs (Wang et al., 2013).

Table S2: DBP formation from different chlorinated precursors at $\mathrm{pH} 7.0$

\begin{tabular}{|l|l|l|l|l|}
\hline & $\begin{array}{l}\text { THM } \\
(\mu \mathrm{mol} / \mathrm{mgDOC})\end{array}$ & $\begin{array}{l}\text { HAA } \\
(\mu \mathrm{mol} / \mathrm{mgDOC})\end{array}$ & $\begin{array}{l}\text { HAN } \\
(\mu \mathrm{mol} / \mathrm{mgDOC})\end{array}$ & Reference \\
\hline Particles & 4 & 9.6 & 1.6 & Hansen et al., 2012b \\
\hline BFA & 0.077 & 0.27 & 0.025 & Hansen et al. 2011 \\
\hline BFA & 0.25 & 0.51 & N.D & Kanan and Karanfil, 2011a \\
\hline NOM & 0.62 & 0.26 & N.D & Kanan and Karanfil, 2011a \\
\hline
\end{tabular}

\section{Emerging precursors in swimming pools}

Advances in analytical methods have allowed to detect and measure many emerging organic compound originating from human inputs in swimming pools (Richardson and Kimura, 2016). Most of these compounds are ingredients of personal care products (PCPs) and sometimes of pharmaceuticals. Personal care products (PCPs) constitute a diverse group of products including lotions, sunscreens, perfumes, and cosmetic creams. Since PCPs are applied externally on the 
human body, their ingredients can be released upon immersion of swimmers into water. Among the ingredients that can be found in PCPs, there are disinfectants (e.g. triclosan), fragrances (e.g. musks), insect repellants (e.g. DEET), preservatives (e.g. parabens) and UV filters (e.g. methylbenzylidene camphor) (Ternes et al., 2004). Parabens or their salts, which are widely used as preservatives in pharmaceuticals and PCPs, have been detected and quantified in swimming pool waters (Alcudia-León et al., 2013; Terasaki and Makino, 2008). In addition, several pharmaceutical compounds including atenolol, carbamazepine, hydrochlorothiazide, metronidazole, ofloxacin, sulfamethoxazole, acetaminophen, ibuprofen, ketoprofen and phenazone were detected in swimming pools and spas in Spain (Ekowati et al., 2016). Teo et al. (2016) reported the detection of ibuprofen and caffeine in Australian swimming pools. Urination in swimming pools can be a potential route for pharmaceuticals into the pool water, especially that certain pharmaceutical are secreted unchanged in urine (Richardson and Bowron, 1985; Weng et al., 2014). Recently, Sharifan et al. (2016) estimated that considerable amounts of UV filters are introduced into pools, prompting a call for an urgent investigation regarding the potential toxic effects of UV filter transformation products and DBPs originating from them. Organic UV filters are increasingly used due to concerns about adverse health effects of exposure to sunlight. Organic UV filters can be found in sunscreens and in other PCPs, such as cosmetics, beauty creams, skin lotions, lipsticks, hair sprays, hair dyes, and shampoos (Ramos et al., 2015; Silvia Díaz-Cruz et al., 2008). Several studies conducted in different countries have reported the occurrence of UV filters in swimming pools. The concentrations of UV filters occurring in the pools varied considerably between different surveys with detected levels ranging from the sub nanogram to the microgram per liter orders (Ekowati et al., 2016; Lambropoulou et al., 2002; Zwiener et al., 2007). The levels of UV filters quantified in pools in different countries so far are summarized in Table 5. PCPs and other emerging contaminants, similarly to other organic precursors, react with chlorine leading to the formation of DBPs. For this reason, the occurrence of pharmaceuticals and PCPs in swimming pool waters has raised concerns about their potentially toxic byproducts (Bottoni et al., 2014). Although several studies have analyzed the occurrence of these compounds in swimming pools, data about their degradation and transformation products in chlorinated media are very limited. Shen and Andrews (2011) demonstrated the potential of a group of pharmaceuticals and PCPs containing amine groups to serve as nitrosamine precursors during disinfection. Kuhlich et al. (2011) investigated the reactions of chlorine with the two 
polycyclic musks 6-acetyl-1,1,2,4,4,7-hexamethyltetraline (AHTN) and 1,3,4,6,7,8-hexahydro4,6,6,7,8,8-hexamethylcyclopentag-2-benzopyran (HHCB), widely used as fragrances in cosmetics. AHTN chlorination generated two new chlorinated DBPs. Studies on the fate of UV filters in chlorinated waters such as swimming pools are rather scarce (Santos et al., 2012). Sakkas et al. (2003) studied the behavior of the UV filter octyl-dimethyl-p-aminobenzoic acid (ODPABA) in various aqueous solutions and identified several chlorinated byproducts originating from the UV filter. Negreira et al. (2008) investigated the fate of the UV filters ethylhexyl salicylate (EHS), ODPABA, and 2-hydroxy-4-methoxybenzophenone (BP-3, OXY) in chlorinated aqueous solutions. EHS showed an acceptable stability whereas BP-3 and ODPABA reacted with free chlorine at significant rates following pseudo-first-order kinetics. The reaction of chlorine with OXY and ODPABA involved electrophilic aromatic substitutions. Monohalogenated and dihalogenated byproducts of OXY were detected. Halogenated 3methoxyphenol was also detected as a cleavage byproduct.

Table 5: Levels of UV filters in swimming pools detected in previous studies

\begin{tabular}{|c|c|c|c|c|c|c|c|c|}
\hline \multirow[b]{2}{*}{ Country } & \multirow[b]{2}{*}{ Type of pool } & \multicolumn{6}{|c|}{ UV filter Concentrations ( $\mathrm{ng} \mathrm{L}^{-1}$ ) } & \multirow[b]{2}{*}{ Reference } \\
\hline & & $\mathrm{OXY}(\mathrm{BP} 3)$ & ODPABA & 4-MBC & $\mathrm{OMC}$ & $\mathrm{OC}$ & PBS & \\
\hline Greece & Swimming pool & $2400-3300$ & 2100 & & & & & Lambropoulou et al. (2002) \\
\hline \multirow[t]{2}{*}{ Greece } & Swimming pool & 4.2 & & 6.9 & 4.5 & & & \multirow[t]{2}{*}{ Giokas et al. (2004) } \\
\hline & Game pool & 5.7 & & 5.4 & 3.0 & & & \\
\hline \multirow[t]{3}{*}{ Germany } & Swimmer pool & & & & 1800 & 7000 & 0.7 & \multirow[t]{3}{*}{ Zwiener et al. (2007) } \\
\hline & Non-swimmer pool & & & & 2700 & 11000 & 2 & \\
\hline & Baby pool & 1200 & & & 7000 & 25000 & 16 & \\
\hline Slovenia & swimming pool & 400 & 17 & 330 & & 15 & & Cuderman and Heath (2007) \\
\hline Spain & Swimming pool & $<$ LOD-2326 & & $43-4035$ & $107-1462$ & $1421-25967$ & & Negreira et al. (2010) \\
\hline Italy & Swimming pool (seawater) & $25-216$ & & & $53-86$ & & & Nguyen et al. (2011) \\
\hline Czech Republic & Swimming pool(outdoor) & $26-620$ & & & & & $240-13000$ & Grabicova et al. (2013) \\
\hline \multirow[t]{5}{*}{ Spain } & Swimming pool (Indoor) & $<0.1-4.87$ & $<0.1$ & $<0.4-5.6$ & & & & \multirow[t]{5}{*}{ Ekowati et al. (2016) } \\
\hline & Swimming pool (outdoor) & $<0.1-15.17$ & $<0.1-2.0$ & $<0.4-35.9$ & & & & \\
\hline & Children pool (indoor) & $<0.1-1.77$ & $<0.1$ & $8.6-12.1$ & & & & \\
\hline & Children pool (outdoor) & $<0.1-1.97$ & $<0.1$ & $8.1-45.4$ & & & & \\
\hline & Spa & $<0.1-1.07$ & $<0.1$ & $<0.4-69.3$ & & & & \\
\hline
\end{tabular}

Nakajima et al., 2009 investigated the reactions of the UV filters ODPABA and octyl-4methoxycinnamate (OMC) with chlorine in aqueous solution under conditions that simulate those found in swimming pools. ODPABA reacted rapidly with chlorine while OMC reacted slowly under the same conditions. The difference in reactivity was attributed to the effect of substituents present on the benzene ring. Both UV filters produced monochlorinated and dichlorinated transformation products. The structures of the chlorinated byproducts were not identified. The chlorination products of OMC exhibited weak mutagenic activity on Salmonella typhimurium TA100 strain in the Ames test. Duirk et al. (2013) studied the transformation of the two benzophenone UV filters OXY and DIOXY in the presence of excess aqueous chlorine. Both UV 
filters were rapidly transformed by aqueous chlorine in a second-order reaction, first order with respect to each reactant. Authors detected chloroform as a stable transformation product resulting from the reaction of chlorine with OXY and DIOXY. Chloroform yields at $\mathrm{pH} 8$ were 0.221 and 0.212 for OXY and DIOXY, respectively. These yields are similar to the average yields for phenols and substituted phenols (Gallard and von Gunten, 2002). Wang et al. (2013) found that some sunscreens and PCPs produced halobenzoquinones when chlorinated swimming pool water. Li et al. (2016) studied the reactivity of a group of benzophenone-type UV filters with chlorine in aqueous solutions. Second-order reactions were found to take place between chlorine and the UV filters OXY, 4-hydroxybenzophenone, and 2-hydroxy-4-methoxybenzophenone-5-sulfonic acid. Authors identified several transformation products and proposed transformation pathways that include electrophilic substitutions, methoxyl substitutions, ketone group oxidations, hydrolysis, decarboxylation, and ring cleavage reactions. Authors also tested the toxicity of the chlorinated UV filters on the luminescent bacteria Photobacterium phosphoreum. Most of the UV filters exhibited higher toxicities after chlorination.

\section{Toxicity and Human Health Effects of DBPs}

Swimming pool users can be exposed to DBPs through multiple routes: dermal absorption, inhalation, and ingestion (Chowdhury et al., 2014; Zwiener et al., 2007). Many in vitro and in vivo toxicological studies have provided evidence about toxic effects induced by DBPs. Epidemiological studies have suggested associations between exposure to DBPs and adverse health effects in humans.

\section{Toxicological studies}

\section{Toxicity of pool waters}

Few studies have analyzed the mutagenic potential of swimming pool water. Honer et al. (1980) assessed the mutagenic potential of water samples obtained from three public indoor pools in Canada and detected positive mutagenic activity using the Ames test in Salmonella typhimurium TA100. Richardson et al. (2010) tested the mutagenicity of water samples obtained from brominated and chlorinated pools. Samples of both pools exhibited mutagenic activity similar to the average mutagenicity of drinking waters. Glauner et al. (2005) evaluated the genotoxicity of different fractions of DBPs present in swimming pool water and found that the strongest 
mutagenic activity was induced by the low-molecular-weight fraction. Liviac et al. (2010) analyzed the genotoxicity of water concentrates of recreational pools under different disinfection treatments and that of source tap water used in filling the pools. Authors detected higher genotoxic activity induced by the recreational pool water compared to source tap water. Plewa et al. (2011) compared the mammalian cell cytotoxity of various recreational pool water samples issued from the same tap water source and showed that the whole disinfected waters samples (indoor and outdoor) were more cytotoxic than raw water. Daiber et al. (2016) studied the progressive increase of water mutagenicity from tap water to swimming pool and spa waters, disinfected by chlorine, ozone or bromine, using the Salmonella assay. In this latter study, the mutagenicity correlated very well with the heavy use of pools, and therefore with the levels of DBPs (especially the nitrogenous brominated compounds).

\section{Toxicity of DBPs}

Numerous studies have investigated the toxicological effects induced by DBPs. However, most of these studies focused on few toxicity endpoint, mainly genotoxicity, carcinogenicity, and reproductive effects (Villanueva et al., 2015). Experimental evidence has been provided in many investigations regarding the genotoxicity of numerous DBPs (Guha et al., 2012; Villanueva et al., 2015). Richardson et al. (2007) reviewed comprehensively the reported data about the genotoxicity and carcinogenicity of 85 DBPs. Table 6 summarizes of well-documented genotoxic and/or carcinogenic effects of THMs, HAAs, and trihaloacetaldehydes (ANSES, 2011). Table S3 presents the known Toxicological Reference Values (TRV) of several DBPs, defined as priority substances to be monitored in French swimming pools (ANSES, 2011). Generally, N-containing DBPs exhibit higher genotoxic potencies than C-containing DBPs (Muellner et al., 2007; Plewa et al., 2008). Furthermore, brominated DBPs are more genotoxic than the chlorinated compounds, while iodinated DBPs were the most genotoxic of all (Jeong et al., 2015; Plewa et al., 2010, 2002; Richardson et al., 2007; Yang et al., 2014). In a recent study, CH was shown not to induce genotoxic effects, while $\mathrm{BH}$ induced mutations and DNA damage but not chromosomal aberrations (Manasfi et al., 2017a). Plewa et al. (2015) compared the toxicity of six DBP classes by assessing their cytotoxicities to chinese hamster ovary (CHO) cells. 
Table S3: Toxicological Reference Values (TRV) of main DBPs

\begin{tabular}{|c|c|c|c|c|c|c|c|c|c|c|c|c|}
\hline Compound & \#CAS & Genotoxicity & $\begin{array}{c}\text { IARC } \\
\text { evaluation }\end{array}$ & Carcinogenic risk & Reprotoxic risk & $\begin{array}{l}\text { Treshold } \\
\text { (yes/no) }\end{array}$ & Route of exposur & rCritical effect & $\begin{array}{l}\text { Origin and year of } \\
\text { the constructed TRV }\end{array}$ & TRV & Critical dose & Species \\
\hline \multirow{2}{*}{ Chloroform } & $67-66-3$ & no & $2 \mathrm{~B}$ & yes (in the animal) & Yes & yes & inhalation & renal cell proliferation, precursor of cancer & Afsset (2008) & $63 \mu \mathrm{g} \cdot \mathrm{m}^{-3}$ & NOAEL $=5 \mathrm{ppm}$ or $25 \mathrm{mg} \cdot \mathrm{m}^{-3}$ & male miceBDF1 \\
\hline & & & & & & yes & ingestion & hepatotoxicity & US EPA (1998) & $0.01 \mathrm{mg} \cdot \mathrm{kg}^{-1}-\mathrm{d}^{-1}$ & LOAEL $=15 \mathrm{mg} \cdot \mathrm{kg}^{-1} \cdot \mathrm{d}^{-1}$ & $\operatorname{dog}$ \\
\hline \multirow[t]{2}{*}{ Chlorodibromethane } & $124-48-1$ & yes (IARC) & 3 & no & no & yes & force-feeding & hepatotoxicity & US EPA (1991) & $2 \cdot 10^{-2} \mathrm{mg} \cdot \mathrm{kg}^{-1} \cdot \mathrm{d}^{-1}$ & NOAEL $=21.4 \mathrm{mg} \cdot \mathrm{kg}^{-1} \cdot \mathrm{d}^{-1}$ & Rats F344 et mices B6C3F1 \\
\hline & & & & & & no & force-feeding & carcinoma and hepatocellular adenoma & US EPA (1991) & $8 \cdot 42 \cdot 10^{-2} \mathrm{mg} \cdot \mathrm{kg}^{-1} \cdot \mathrm{d}^{-1}$ & LMS model & Rats F344 et mices B6C3F1 \\
\hline \multirow[t]{2}{*}{ Bromodichloromethane } & $75-27-4$ & yes (A) & $2 B$ & yes (in animals) & No & yes & force-feeding & renal citomegalia & US EPA (1987) & $2 \cdot 10^{-2} \mathrm{mg} \cdot \mathrm{kg}^{-1} \cdot \mathrm{d}^{-1}$ & LOAEL $=17.9 \mathrm{mg} \cdot \mathrm{kg}^{-1} \cdot \mathrm{d}^{-1}$ & Rats F344 et mices B6C3F1 \\
\hline & & & & & & no & force-feeding & Adenoma and adenocarcinoma of renal tubular cells & US EPA (1987) & $6 \cdot 2 \cdot 10^{-2} \mathrm{mg} \cdot \mathrm{kg}^{-1} \cdot \mathrm{d}^{-1}$ & LMS model & Rats F344 et mices B6C3F1 \\
\hline \multirow{3}{*}{ Bromoform } & \multirow{3}{*}{$75-25-2$} & \multirow{3}{*}{ yes (A) } & \multirow{3}{*}{3} & \multirow{4}{*}{ no } & \multirow{3}{*}{ yes } & no & inhalation & neoplastic lesion in the large intestine & US EPA (1991) & $1.10^{-6} \mu \mathrm{g} \cdot \mathrm{m}^{-3}$ & LMS model & Rats F344 et mices B6C3F1 \\
\hline & & & & & & yes & force-feeding & liver damages & US EPA (1991) & $2 \cdot 10^{-2} \mathrm{mg} \cdot \mathrm{kg}^{-1} \cdot \mathrm{d}^{-1}$ & NOAEL : $17.9 \mathrm{mg} \cdot \mathrm{kg}^{-1} \cdot \mathrm{d}^{-1}$ & Rats F344 et mices B6C3F1 \\
\hline & & & & & & no & force-feeding & neoplastic lesion in the large intestine & US EPA (1991) & $7.9 \cdot 10^{-3} \mathrm{mg} \cdot \mathrm{kg}^{-1} \cdot \mathrm{d}^{-1}$ & LMS model & Rats F344 et mices B6C3F1 \\
\hline Trichloramine & $10025-85-1$ & & & & & yes & inhalation & $\begin{array}{l}\text { increase in serum level of SPA and SPB } \\
\text { pneuproteins }\end{array}$ & EHESP (2009) & $4 \cdot 10^{-3} \mathrm{mg} \cdot \mathrm{m}^{-3}$ & $0.355 \mathrm{mg} \cdot \mathrm{m}^{-3}$ & Human \\
\hline \multirow{2}{*}{ Chloral hydrate } & \multirow[t]{2}{*}{$302-17-0$} & \multirow[t]{2}{*}{ ambiguous } & \multirow[t]{2}{*}{3} & yes (in mice) & yes (in animals) & yes & ingestion & $\begin{array}{l}\text { depression of the central nervous system and } \\
\text { gastrointestinal irritations }\end{array}$ & US EPA (2000) & $0.1 \mathrm{mg} \cdot \mathrm{kg}^{-1} \cdot \mathrm{d}^{-1}$ & LOAEL: $10.7 \mathrm{mg} \cdot \mathrm{kg}^{-1} \cdot \mathrm{d}^{-1}$ & Human \\
\hline & & & & & & yes & ingestion & Adenoma and hepatic carcinoma & Sante canada (2008) & $0.0045 \mathrm{mg} \cdot \mathrm{kg}^{-1} \cdot \mathrm{d}^{-1}$ & $13.5 \mathrm{mg} \cdot \mathrm{kg}^{-1} \cdot \mathrm{d}^{-1}$ & Rats F344 et mices B6C3F1 \\
\hline $\mathrm{N}$-nitrosodimethylamine & $62-75-9$ & Yes & $2 \mathrm{~A}$ & yes (in mice) & yes (in animals) & no & ingestion & induction of liver tumours & US EPA (1993) & $51 \mathrm{mg} \cdot \mathrm{kg}^{-1} \cdot \mathrm{d}^{-1}$ & Weibull method & Colwoth female rats \\
\hline Chloroacetic acid & $79-11-8$ & No & & no & yes (in animals) & yes & force-feeding & change in body, kidney, liver and testis weight & Sante canada (2008) & $0.0117 \mathrm{mg} \cdot \mathrm{kg}^{-1} \cdot \mathrm{d}^{-1}$ & $13.5 \mathrm{mg} \cdot \mathrm{kg}^{-1} \cdot \mathrm{d}^{-1}$ & Rats \\
\hline \multirow{3}{*}{ Dichloroacetic acid } & \multirow{3}{*}{$79-43-6$} & \multirow{3}{*}{ yes (IARC) } & \multirow{3}{*}{$2 \mathrm{~B}$} & \multirow{3}{*}{ yes } & yes (in animals) & yes & ingestion & testiuclar, liver and brain lesions & US EPA (2003) & $4 \cdot 10^{-3} \mathrm{mg} \cdot \mathrm{kg}^{-1} \cdot \mathrm{d}^{-1}$ & LOAEL: $12.5 \mathrm{mg} \cdot \mathrm{kg}^{-1} \cdot \mathrm{d}^{-1}$ & Beagle dogs \\
\hline & & & & & & no & ingestion & liver tumour and hepatocellular carcinoma & Sante canada (2008) & $1.02 \cdot 10-6 \mathrm{mg} \cdot \mathrm{kg}^{-1} \cdot \mathrm{d}^{-1}$ & model & BCF63F1 male mices \\
\hline & & & & & & no & ingestion & hepatoadenoma and hepatocarcinoma & US EPA (2003) & $0.015 \mathrm{mg} \cdot \mathrm{kg}^{-1} \cdot \mathrm{d}^{-1}$ & BMD & BCF63F1 male mices \\
\hline Trichloroacetic acid & 76-03-9 & no (IARC) & 3 & yes (in mice) & yes (in animals) & yes & ingestion & change in body weight and increase in hepatic enzyms & r Sante canada (2008) & $0.0325 \mathrm{mg} \cdot \mathrm{kg}^{-1} \cdot \mathrm{d}^{-1}$ & $32.5 \mathrm{mg} \cdot \mathrm{kg}^{-1} \cdot \mathrm{d}^{-1}$ & Rats \\
\hline Bromoacetic acid & 79-08-3 & no & 3 & no & yes (in animals) & & & & & & & \\
\hline \multirow{2}{*}{ Dibromoacetic acid } & 631-64-1 & yes & & no & yes (in animals) & no & ingestion & malignant mesothelioma & Sante canada (2008) & $4 \cdot 26 \cdot 10^{-6} \mathrm{mg} \cdot \mathrm{kg}^{-1} \cdot \mathrm{d}^{-1}$ & LMS model & BCF63F1 male mices \\
\hline & & & & & & no & ingestion & hepatoadenoma and hepatocarcinoma & Sante canada (2008) & $0.14 \cdot 10^{-6} \mathrm{mg} \cdot \mathrm{kg}^{-1} \cdot \mathrm{d}^{-1}$ & LMS model & BCF63F1 male mices \\
\hline Dichloroacetonitrile & 3018-12-0 & \multirow{3}{*}{ yes (A) } & \multirow{3}{*}{3} & \multirow{3}{*}{ no } & & & & & & & & \\
\hline Dibromoacetonitrile & $3252-43-5$ & & & & & & & & & & & \\
\hline Trichloroacetonitrile & $545-06-2$ & & & & & & & & & & & \\
\hline EL: INo Unservable A & idverse Effec & t Level; LC & Lov & erved & t Level & & & & & & & \\
\hline
\end{tabular}


The rank order of cytotoxicity was haloacetamides $>$ HALs $>$ halonitromethanes $>$ HAAs $>$ HANs > THMs. Among HALs the rank order of cytotoxicity was tribromoacetaldehyde (TBAL) $\approx$ chloroacetaldehyde $(\mathrm{CAL})>$ dibromoacetaldehyde $(\mathrm{DBAL}) \approx$ bromochloroacetaldehyde $(\mathrm{BCAL}) \approx$ dibromochloroacetaldehyde $(\mathrm{DBCAL})>\mathrm{IAL}$ (iodoacetaldehyde) > bromoacetaldehyde $(\mathrm{BAL}) \approx$ bromodichloroacetaldehyde $(\mathrm{BDCAL})>$ dichloroacetaldehyde $(\mathrm{DCAL})>$ trichloroacetaldehyde (TCAL). However, despite these studies, there are still data gaps with regard to the cytotoxicity and genotoxicity of DBPs (Richardson et al., 2007; Richardson and Postigo, 2011). Experiments conducted in vivo have shown that certain DBPs are carcinogenic (Boorman, 1999; Melnick et al., 2007; Richardson et al., 2007). In addition, investigations conducted in animals have provided evidence about the potential of DBPs to induce a range of adverse reproductive effects such as reduced fetal growth, sperm toxicity, and teratogenicity (Tardiff et al., 2006).

Table 6: Genotoxicity and carcinogenicity of THMs and HAAs

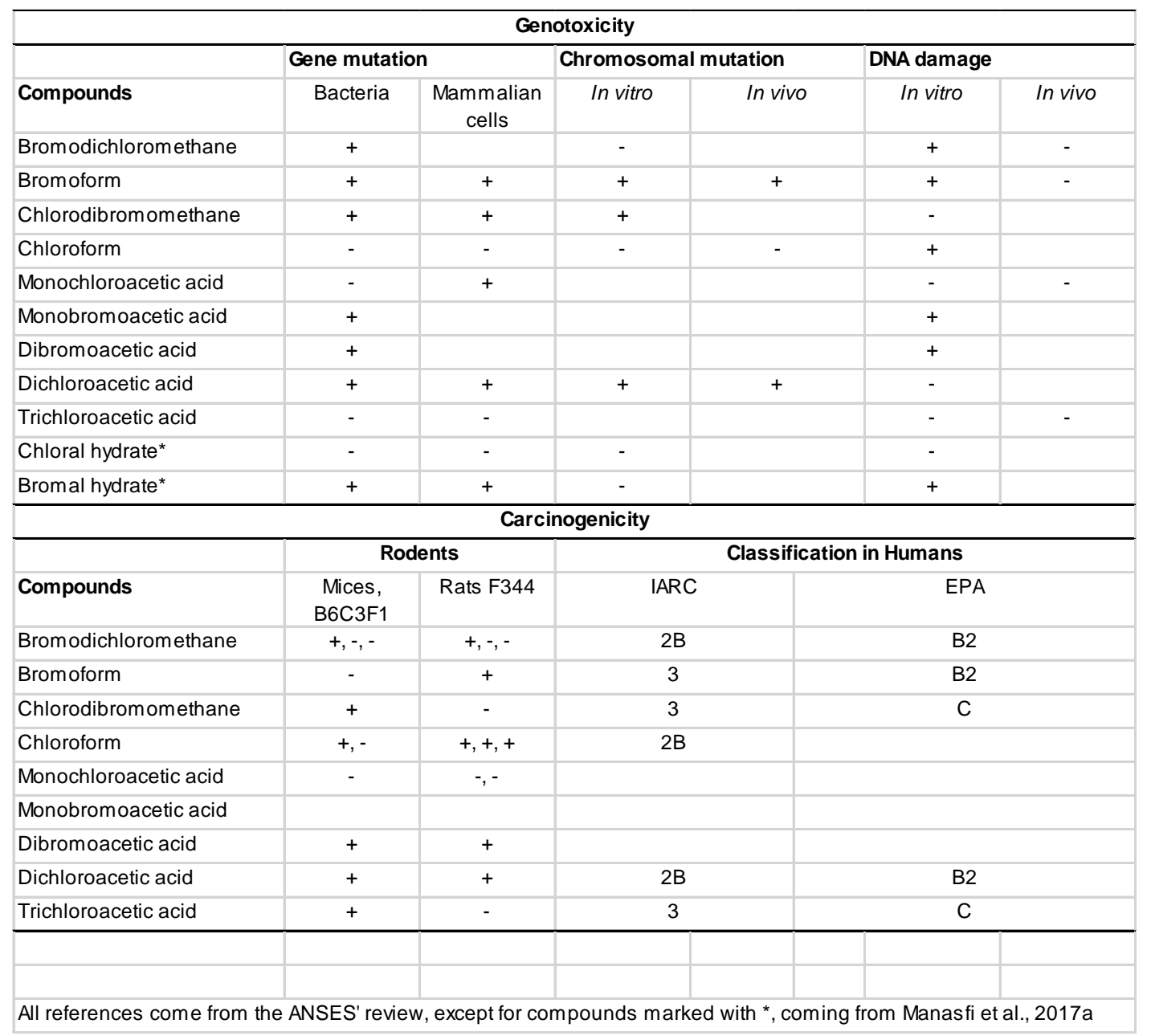


Few studies focused on the neurotoxicity of DBPs. Dichloroacetic acid (DCAA) and dibromoacetic acid (DBAA) were found to induce neurotoxic effects in rats (Moser et al., 2004, 1999). More recently, THMs and tetrachloroethylene were shown to induce autistic-like behaviors in male mice (Guariglia et al., 2011). HAAs have been identified as being genotoxic and cytotoxic and able to induce cellular DNA damage and oxidative stress response via several pathways. Some toxicological studies showed that HAAs are more carcinogenic than THMs with DCAA and TCAA producing liver tumors in rodents (Righi et al., 2014). DCAA has been classified by IARC as possibly carcinogenic to humans (group 2B). Moreover, DCAA and TCAA induce both developmental and teratogenic effects in rats including low birthweight, cardiovascular and urogenital malformations and reproductive effects, such as lower sperm numeration (Righi et al., 2014).

\section{Epidemiological studies in Humans}

\section{Respiratory effects}

Several epidemiological studies have investigated the respiratory effects of chronic swimming pool attendance for workers, elite swimmers, and children. Exposure to DBPs was associated with higher prevalence of adverse respiratory effects among pool workers (Fantuzzi et al., 2010; Jacobs et al., 2007; Massin et al., 1998). Some studies have described higher prevalence of asthma among elite swimmers (Fisk et al., 2010). Some surveys have demonstrated associations between regular attendance at chlorinated pools and increased risk of asthma in children (Bernard et al., 2006, 2003; Langerkvist et al., 2004; Nickmilder and Bernard, 2006). Also, investigations have suggested increased risk of recurrent respiratory tract infections and otitis media linked to baby swimming (Nystad et al., 2007). Exposure to trichloramine, a volatile irritant DBP in indoor pools, has often been associated with an increased risk of respiratory effects in highly exposed populations (Florentin et al., 2011; Villanueva et al., 2015). Recent studies clearly demonstrated uptake of DBPs during swimming, by measuring levels of THMs in exhaled breath of swimmers,

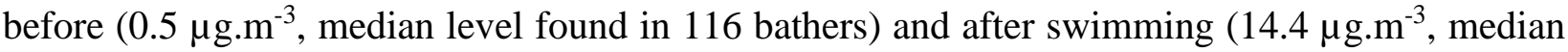
level). Moreover, a direct correlation between levels of brominated THMs measured in air levels found in exhaled breath was detected, despite variations observed according to sex, physical activity and polymorphisms in key metabolic enzymes (Marco et al., 2015; Font-Ribera et al., 
2016). Exposure of swimmers and workers to THMs had been also previously reported in several past studies (Caro and Gallego, 2008; Kogevinas et al., 2010; Lourencetti et al., 2010; Nieuwenhuijsen et al., 2000; Xu and Weisel, 2005). However, some studies have claimed that swimming is beneficial for children and adolescents with asthma (Matsumoto et al., 1999; Rosimini, 2003). Current evidence of an association between childhood swimming and new-onset asthma is suggestive but not conclusive (Weisel et al., 2009). Inconsistent findings have been continuously reported in studies that are more recent. In a prospective longitudinal epidemiologic study, no significant association was found between increased risk of asthma or allergic symptoms and swimming pool attendance in British children. The study suggested that swimming was associated with increased lung function and lower risk of asthma symptoms, especially among children with preexisting respiratory conditions (Font-Ribera et al., 2012). On the other hand, a more recent study conducted in Sweden supported the proposed link between indoor swimming pool attendance and asthma in sensitized children (Andersson et al., 2015). Further well-designed studies with defined asthma outcomes are still needed to provide conclusive evidence about the relationship between swimming pool attendance and childhood asthma.

\section{Cancer}

Several epidemiological studies have demonstrated evidence for a relationship between exposure to DBPs and increased risks of bladder cancer (Cantor et al., 2010; Nieuwenhuijsen et al., 2009; Villanueva et al., 2004). Two studies evaluated specifically the exposure to DBPs through swimming pool attendance and found increased risk of bladder cancer among attending subjects mainly related to THM exposure through showering, bathing, and swimming (Villanueva et al., 2007). Panyakapo et al. (2008) showed that the risk of developing cancer exists in swimmers exposed to THM from pool and tap water, and that the dermal route accounts for $94.2 \%$ of the total THM exposure for swimmers. Some studies have suggested associations between exposure to DBPs and other types of cancer including colorectal and skin cancer (Nelemans et al., 1994; Rahman et al., 2010). However, evidence about such associations remains inconclusive and inconsistent (Hrudey, 2009; Nieuwenhuijsen et al., 2009; Villanueva et al., 2015). 


\section{Reproductive effects}

Because of toxicological studies detecting adverse reproductive effects in animals, reproductive health outcomes such as low birthweight, prematurity, spontaneous abortion, congenital anomalies and stillbirth have been the focus of epidemiological studies. Studies have provided some evidence for a relationship between exposure to DBPs and small for gestational age/intrauterine growth retardation and preterm delivery. However, evidence for other outcomes such as low birthweight, stillbirth, congenital anomalies and semen quality appears to be inconclusive and inconsistent (Hinckley et al., 2005; Hrudey, 2009; Nieuwenhuijsen et al., 2009, 2000; Tardiff et al., 2006; Villanueva et al., 2015).

\section{Conclusion}

This paper reviewed the occurrence, origin, and toxicity of DBPs in swimming pools disinfected with chlorine. In terms of occurrence, haloamines, HAAs, THMs, HANs and HALs are the byproducts largely present in water of swimming pools treated with chlorine. Recent studies have provided evidence about the occurrence of other emerging DBP that are toxic, even at low concentrations, including nitrogenous DBPs such as N-nitrosamines, HNMs, nitramines, nitramides, and cyanogen halides as well as carbonaceous DBPs such as halobenzoquinones, haloketones, halofuranones. Although more than 100 DBPs have been identified so far (Richardson et al., 2010), we have to keep in mind that these compounds represent only a small fraction of the total organic halide (TOX) contents detected in chlorinated swimming pool waters (Richardson et al., 2010; Freyfer, 2012; Manasfi et al., 2017b). It is thus important to continue to investigate the nature and levels of occurrence of DBPs in pool waters so that the unknown DBPs contributing to the TOX contents could be determined. In addition, further research is required to analyse the exposure of bathers to the emerging DBPs in swimming pools and to investigate their potential health effects. Indeed, if ocular, respiratory, and cutaneous irritations seem well correlated with the presence of trichloramine and dichloromethylamine in swimming pool water, relationships between pool attendance and other adverse health effects such as asthma, different cancers, and reproductive outcomes prompt further investigations (Kogevinas et al., 2010; FontRibera et al., 2012). 
The identification and quantification of DBPs in swimming pools is analytically challenging given the complexity of swimming pool water chemistry. The nature of human inputs varies considerably not only as a function of bathers' hygiene but also as a function of activities carried out in pools (relaxing, sport, therapeutic pools ...). Furthermore, pool location (indoor ou outdoor) as well as maintenance conditions applied by pool operators, such as ventilation, rates of water renewal, adjustment of chlorine or chlorine-based disinfectant levels (depending on local regulations), and use of additives (e.g. stabilizers) can all have an impact on the occurrence of DBPs in pool water and ambient air. Moreover, the nature and levels of DBPs are clearly modified when treatments other than chlorine-based disinfection, such as ozone, ozone/chlorine, ozone/UV or UV/chlorine, are applied. Few papers compared the impact of different disinfection treatment on the toxicity of generated DBPs in swimming pools. However, the reported findings with regard to toxicity variation from one treatment to another were often conflicting (Plewa et al., 2011; Hansen et al., 2013; Solterman et al., 2013; Cimetiere and De Laat, 2014; Spiliotopoulou et al., 2015).

Data presented in this review with regard to the occurrence, toxicity, and toxicological reference values of DBPs could be used in conducting risk assessment studies for swimming pools. However, to be robust, these studies need to be correlated to daily exposure doses, and to the characteristics of people attending swimming pools (occasional swimmers, elite swimmers, baby swimmers, pregnant women, technical staff ...). Volatile DBPs can be inhaled and the inhaled amounts depend on the mode of breathing, oral or nasal (Bernard et al., 2007). Swimmers can be also exposed to DBPs when water is accidently ingested. The average ingested volume varies largely as a function of swimmer categories and for the same category considerable differences have been reported in different studies (from $25 \mathrm{~mL} \mathrm{~h}^{-1}$ to $50 \mathrm{~mL} \mathrm{~h}^{-1}$ for babies, from 20 to $25 \mathrm{~mL}$ $\mathrm{h}^{-1}$ for swimmers, and from 170 to $225 \mathrm{~mL} \mathrm{~h}^{-1}$ for elite swimmers) (Dufour et al., 2006; WHO, 200). Another route of exposure of swimmers to DBPs is through dermal absorption. Some DBPs can cross the cutaneous barrier but the limited data available make difficult determining the contribution of the dermal exposure route to the overall exposure. Biomonitoring and investigations about the pharmacokinetic profiles of DBPs would provide data that is vital to improve risk assessment studies. In addition, a better understanding of the occurrence of DBPs in swimming pools, their formation and transformation mechanisms, and their toxicity, is required 
so that efficient preventive measures could be taken to reduce their formation and to minimize the exposure of swimmers to these chemical contaminants.

\section{References}

Acero, J.L., Piriou, P., Von Gunten, U., 2005. Kinetics and mechanisms of formation of bromophenols during drinking water chlorination: Assessment of taste and odor development. Water Res. 39, 2979-2993. doi:10.1016/j.watres.2005.04.055

Aggazzotti, G., Predieri, G., 1986. Survey of volatile halogenated organics (VHO) in Italy. Levels of VHO in drinking waters, surface waters and swimming pools. Water Res. 20, 959-963. doi:10.1016/0043-1354(86)90036-9

Alcudia-León, M.C., Lucena, R., Cárdenas, S., Valcárcel, M., 2013. Determination of parabens in waters by magnetically confined hydrophobic nanoparticle microextraction coupled to gas chromatography/mass spectrometry. Microchem. J. 110, 643-648. doi:10.1016/j.microc.2013.07.011

Andersson, M., Hedman, L., Nordberg, G., Forsberg, B., Eriksson, K., Rönmark, E., 2015. Swimming pool attendance is related to asthma among atopic school children: a populationbased study. Environ. Heal. 14, 37. doi:10.1186/s12940-015-0023-X

ANSES (French Agency for Food, Environmental and Occupational Health and Safety), 2011. Evaluation des risques sanitaires liés aux piscines. Partie I : piscines réglementées. Ed. ANSES, 244 pp (report in French available at : https://www.anses.fr/fr/system/files/EAUX2007sa0409Ra.pdf)

ANSES (French Agency for Food, Environmental and Occupational Health and Safety), 2013. Evaluation des risques sanitaires liés aux piscines. Partie II : bains à remous. Ed. ANSES, 202 pp (report in French available at : https://www.anses.fr/fr/system/files/EAUX2007sa0409Ra-2.pdf)

Beech, J., Diaz, R., Ordaz, C., Palomeque, B., 1980. Nitrates, chlorates and trihalomethanes in swimming pool water. Am. J. Public Health 70, 79-82. doi:10.2105/AJPH.70.1.79 
Bellar, T.A., Lichtenberg, J.J., Kroner, R.C., 1974. The Occurrence of Organohalides in Chlorinated Drinking Waters (PDF). J. Am. Water Works Assoc. 66, 703-706.

Berg, M., Müller, S. R., Mühlemann, J., Wiedmer, A., Schwartzenbach, R.H., 2000. Concentrations and Mass Fluxes of Chloroacetic Acids and Trifluoroacetic Acid in Rain and Natural Waters in Switzerland. Environ. Sci. Technol. 34 (13) : 2675-2683

Bernard, A., Carbonnelle, S., de Burbure, C., Michel, O., Nickmilder, M., 2006. Chlorinated pool attendance, atopy, and the risk of asthma during childhood. Environ. Health Perspect. 114, 1567-73.

Bernard, A., Carbonnelle, S., Michel, O., Higuet, S., Burbure, C. de, Buchet, J.-P., Hermans, C., Dumont, X., Doyle, I., 2003. Lung hyperpermeability and asthma prevalence in schoolchildren: unexpected associations with the attendance at indoor chlorinated swimming pools. Occup. Environ. Med. 60, 385-394. doi:10.1136/oem.60.6.385

Bessonneau, V., Derbez, M., Clément, M., Thomas, O., 2011. Determinants of chlorination byproducts in indoor swimming pools. Int. J. Hyg. Environ. Health. 215, 76-85.

doi:10.1016/j.ijheh.2011.07.009

Blatchley, E.R., Cheng, M., 2010. Reaction mechanism for chlorination of urea. Environ. Sci. Technol. 44, 8529-8534. doi:10.1021/es102423u

Boorman, G., 1999. Drinking water disinfection byproducts: review and approach to toxicity evaluation. Environ. Health Perspect.

Bottoni, P., Bonadonna, L., Chirico, M., Caroli, S., Záray, G., 2014. Emerging issues on degradation by-products deriving from personal care products and pharmaceuticals during disinfection processes of water used in swimming pools. Microchem. J. 112, 13-16. doi:10.1016/j.microc.2013.09.001

Cantor, K.P., Villanueva, C.M., Silverman, D.T., Figueroa, J.D., Real, F.X., Garcia-Closas, M., Malats, N., Chanock, S., Yeager, M., Tardon, A., Garcia-Closas, R., Serra, C., Carrato, A., Castaño-Vinyals, G., Samanic, C., Rothman, N., Kogevinas, M., 2010. Polymorphisms in GSTT1, GSTZ1, AND CYP2E1, disinfection by-products, and risk of bladder cancer in 
Spain. Environ. Health Perspect. 118, 1545-1550. doi:10.1289/ehp.1002206

Cardador, M.J., Gallego, M., 2011. Haloacetic acids in swimming pools: Swimmer and worker exposure. Environ. Sci. Technol. 45, 5783-5790. doi:10.1021/es103959d

Carro, J., Gallejo, M., 2008. Alveolar air and urine analyses as biomarkers of exposure to trihalomethanes in an indoor swimming pool. Environ. Sci. Technol. 42(13, 5002-5007. doi :10.1021/es800415p

Catto, C., Simard, S., Charest-Tardif, G., Rodriguez, M., Tardif, R., 2012. Occurrence and Spatial and Temporal Variations of Disinfection By-Products in the Water and Air of Two Indoor Swimming Pools. Int. J. Environ. Res. Public Health. 9, 2562-2586. doi:10.3390/ijerph9082562

Chowdhury, S., Al-hooshani, K., Karanfil, T., 2014. Disinfection byproducts in swimming pool: Occurrences, implications and future needs. Water Res. doi:10.1016/j.watres.2014.01.017

Chowdhury, S., Mazumder, A.J., Husain, T., 2016. Predicting bromide incorporation in a chlorinated indoor swimming pool. Environ. Sci. Pollut. R. 23(12), 12174-12184. doi : 10.1007/s11356-016-6339-4.

Chu, H., Nieuwenhuijsen, M.J., 2002. Distribution and determinants of trihalomethane concentrations in indoor swimming pools. Occup. Environ. Med. 59, 243-247. doi:10.1136/oem.59.4.243

Chu, T.S., Cheng, S.F., Wang, G.S., Tsai, S.W., 2013. Occupational exposures of airborne trichloramine at indoor swimming pools in Taipei. Sci. Total Environ. 461-462, 317-322. doi: 10.1016/j.scitotenv.2013.05.012

Cimetiere, N., De Laat, J., 2009. Henry's law constant of N,N-dichloromethylamine : application to the contamination of the atmosphere of indoor swimming pools. Chemosphere, 77(4), 465-470.

Cimetiere, N., De Laat, J., 2014. Effects of UV-dechloramination of swimming pool water on the formation of disinfection by-products : a lab-scale study. Microchem. J., 112, 34-41. 
Daiber, E.J., DeMarini, D.M., Ravuri, S.A., Liberatore, H.K., Cuthbertson, A.A., ThompsonKlemish, A., Byer, J.D., Schmid, J.E., Afifi, M.Z., Blatchley, E.R., Richardson, S.D., 2016. Progressive Increase in Disinfection Byproducts and Mutagenicity from Source to Tap to Swimming Pool and Spa Water: Impact of Human Inputs. Environ. Sci. Technol. doi:10.1021/acs.est.6b00808

De Laat, J., Feng, W., Freyfer, D.A., Dossier-Berne, F., 2011. Concentration levels of urea in swimming pool water and reactivity of chlorine with urea. Water Res. 45, 1139-1146. doi:10.1016/j.watres.2010.11.005

Deborde, M., von Gunten, U., 2008. Reactions of chlorine with inorganic and organic compounds during water treatment-Kinetics and mechanisms: A critical review. Water Res. 42, 13-51. doi:10.1016/j.watres.2007.07.025

Dufour, A.P., Evans, O., Behymer, T.D., Cantu, R., 2006. Water ingestion during swimming activities in a pool: a pilot study. J. Water Health. 4 (4), 425-430.

Duirk, S.E., Bridenstine, D.R., Leslie, D.C., 2013. Reaction of benzophenone UV filters in the presence of aqueous chlorine: Kinetics and chloroform formation. Water Res. 47, 579-587. doi:10.1016/j.watres.2012.10.021

Ekowati, Y., Buttiglieri, G., Ferrero, G., Valle-Sistac, J., Diaz-Cruz, M.S., Barceló, D., Petrovic, M., Villagrasa, M., Kennedy, M.D., Rodríguez-Roda, I., 2016. Occurrence of pharmaceuticals and UV filters in swimming pools and spas. Environ. Sci. Pollut. Res. 23, 14431-14441. doi:10.1007/s11356-016-6560-1

Erdinger, L., Kühn, K.P., Kirsch, F., Feldhues, R., Fröbel, T., Nohynek, B., Gabrio, T., 2004. Pathways of trihalomethane uptake in swimming pools. Int. J. Hyg. Environ. Health 207, 571-575. doi:10.1078/1438-4639-00329

Fantuzzi, G., Righi, E., Predieri, G., Ceppelli, G., Gobba, F., Aggazzotti, G., 2001. Occupational exposure to trihalomethanes in indoor swimming pools. Sci. Total Environ. 264, 257-265.

Fantuzzi, G., Righi, E., Predieri, G., Giacobazzi, P., Mastroianni, K., Aggazzotti, G., 2010. 
Prevalence of ocular, respiratory and cutaneous symptoms in indoor swimming pool workers and exposure to disinfection by-products (DBPs). Int. J. Environ. Res. Public Health 7, 1379-1391. doi:10.3390/ijerph7041379

Fantuzzi, G., Righi, E., Predieri, G., Giacobazzi, P., Petra, B., Aggazzotti, B., 2013. Airborne trichloramine $\left(\mathrm{NCl}_{3}\right)$ levels and self-reported health symptoms in indoor swimming pool workers : dose-response relationships. J. Expo. Sci. Environ. Epidemiol. 23(1), 88-93.

Fisk, M.Z., Steigerwald, M.D., Smoliga, J.M., Rundell, K.W., 2010. Asthma in swimmers: a review of the current literature. Phys. Sportsmed. 38, 28-34. doi:10.3810/psm.2010.12.1822

Florentin, A., Hautemanière, A., Hartemann, P., 2011. Health effects of disinfection by-products in chlorinated swimming pools. Int. J. Hyg. Environ. Health. 214, 461-469. doi : 10.1016/j.ijheh.2011.07.012

Font-Ribera, L., Villanueva, C.M., Nieuwenhuijsen, M.J., Zock, J.-P., Kogevinas, M., Henderson, J., 2012. Swimming Pool Attendance, Asthma, Allergies, and Lung Function in the Avon Longitudinal Study of Parents and Children Cohort. http://dx.doi.org/10.1164/rccm.201005-0761OC.

Font-Ribera, L., Kogevinas, M., Schmalz, C., Zwiener, C., Marco, E., Grimalt, J.O., Liu, J.Q., Zhang, X.R., Mitch, W., Critelli, R., Naccarati, A., Heederick, D., Spithoven, J., Arjona, L., de Bont, J., Gracia-Lavedan, E., Villanueva, C.M., 2016 Environmental and personal determinants of the uptake of disinfection by-products during swimming. Environ. Res.149, 206-215. doi: 10.1016/j.envres.2016.05.013

Freuze, I., Brosillon, S., Laplanche, A., Tozza, D., Cavard, J., 2005. Effect of chlorination on the formation of odorous disinfection by-products. Water Res. 39, 2636-2642. doi:10.1016/j.watres.2005.04.026

Freyfer, D.A., 2012. Sous-produits de chloration dans les eaux de piscine - Effet de l'ozonation. Thèse de doctorat de l'université de Poitiers, soutenue le 12 décembre 2012, 183 pp.

Gallard, H., Pellizzari, F., Croué, J.P., Legube, B., 2003. Rate constants of reactions of bromine with phenols in aqueous solution. Water Res. 37, 2883-2892. doi:10.1016/S0043- 
1354(03)00132-5

Gallard, H., von Gunten, U., 2002. Chlorination of phenols: Kinetics and formation of chloroform. Environ. Sci. Technol. 36, 884-890. doi:10.1021/es010076a

Gérardin, F., Cloteaux, A., Midoux, N., 2015. Modeling of variations in nitrogen trichloride concentration over time in swimming pool water. Process Saf. Environ. Protect. 94, 452462. doi : 10.1016/j.psep.2014.10.004

Glauner, T., Waldmann, P., Frimmel, F.H., Zwiener, C., 2005. Swimming pool water Fractionation and genotoxicological characterization of organic constituents. Water Res. 39, 4494-4502. doi:10.1016/j.watres.2005.09.005

Guariglia, S.R., Jenkins, E.C., Chadman, K.K., Wen, G.Y., 2011. Chlorination byproducts induce gender specific autistic-like behaviors in CD-1 mice. Neurotoxicology 32, 545-553. doi:10.1016/j.neuro.2011.06.008

Guha, N., Loomis, D., Grosse, Y., Lauby-Secretan, B., El Ghissassi, F., Bouvard, V., BenbrahimTallaa, L., Baan, R., Mattock, H., Straif, K., International Agency for Research on Cancer Monograph Working Group, T., Toikkanen, J., Pedersen, D., al., et, Mirabelli, D., Kauppinen, T., Charbotel, B., Fevotte, J., Hours, M., Martin, J., Bergeret, A., Moore, L., Boffetta, P., Karami, S., al., et, Boice, J., Marano, D., Cohen, S., al., et, Zhao, Y., Krishnadasan, A., Kennedy, N., Morgenstern, H., Ritz, B., Raaschou-Nielsen, O., Hansen, J., Christensen, J., Blot, W., McLaughlin, J., Olsen, J., Scott, C., Jinot, J., Lynge, E., Andersen, A., Rylander, L., al., et, Blair, A., Petralia, S., Stewart, P., Calvert, G., Ruder, A., Petersen, M., Ikbal, M., Tastekin, A., Dogan, H., Pirim, I., Ors, R., 2012. Carcinogenicity of trichloroethylene, tetrachloroethylene, some other chlorinated solvents, and their metabolites. Lancet. Oncol. 13, 1192-3. doi:10.1016/s1470-2045(12)70485-0

Hansen, K.M.S., Willach, S., Mosbæk, H., Andersen, H.R., 2012. Particles in swimming pool filters - Does pH determine the DBP formation? Chemosphere. 87, 241-247. doi:10.1016/j.chemosphere.2012.01.003

Hansen, K.M.S., Albrechtsen, H.-J., Andersen, H.R., 2013. Optimal pH in chlorinated swimming pools - balancing formation of by-products. J. Water Health. 11(3), 465-472. doi : 
10.2166/wh.2013.156.

Hinckley, A.F., Bachand, A.M., Reif, J.S., 2005. Late pregnancy exposures to disinfection byproducts and growth-related birth outcomes. Environ. Health Perspect. 113, 1808-1813. doi:10.1289/ehp.8282

Hoffmann, M., 2015. Ozone-bromine treatment - Water treatment in public pools without chlorine : a new standard? Ozone-Sci. Eng. 37(5), 456-466. doi : 10.1080/01919512.2015.1053014

Honer, W.G., Ashwood-Smith, M.J., Warby, C., 1980. Mutagenic activity of swimming-pool water. Mutat. Res. Toxicol. 78, 137-144. doi:10.1016/0165-1218(80)90092-0

Hrudey, S.E., 2009. Chlorination disinfection by-products, public health risk tradeoffs and me. Water Res. 43, 2057-2092. doi:10.1016/j.watres.2009.02.011

Hua, G., Reckhow, D.A., Kim, J., 2006. Effect of Bromide and Iodide Ions on the Formation and Speciation of Disinfection Byproducts during Chlorination. Environ. Sci. Technol. 40, 3050-3056. doi:10.1021/es0519278

Huang, X., Gao, N., Deng, Y., 2008. Bromate ion formation in dark chlorination and ultraviolet/chlorination processes for bromide-containing waters. J. Environ. Sci. 20(2), 246251. doi: 10.1016/S1001-0742(08)60038-8

Hureiki, L., Croué, J.P., Legube, B., 1994. Chlorination studies of free and combined amino acids. Water Res. 28, 2521-2531. doi:10.1016/0043-1354(94)90070-1

Jacobs, J.H., Spaan, S., van Rooy, G.B.G.J., Meliefste, C., Zaat, V.A.C., Rooyackers, J.M., Heederik, D., 2007. Exposure to trichloramine and respiratory symptoms in indoor swimming pool workers. Eur. Respir. J. 29, 690-8. doi:10.1183/09031936.00024706

Jafvert, C.T., Valentine, R.L., 1992. Reaction scheme for the chlorination of ammoniacal water. Environ. Sci. Technol. 26, 577-586. doi:10.1021/es00027a022

Jeong, C.H., Postigo, C., Richardson, S.D., Simmons, J.E., Kimura, S.Y., Mariñas, B.J., Barcelo, D., Liang, P., Wagner, E.D., Plewa, M.J., 2015. Occurrence and Comparative Toxicity of 
Haloacetaldehyde Disinfection Byproducts in Drinking Water. Environ. Sci. Technol. 49, 13749-13759. doi:10.1021/es506358x

Joo, S.H., Mitch, W.A., 2007. Nitrile, aldehyde, and halonitroalkane formation during chlorination/chloramination of primary amines. Environ. Sci. Technol. 41, 1288-1296. doi:10.1021/es0612697

Judd, S.J., Jeffrey, J. a., 1995. Trihalomethane formation during swimming pool water disinfection using hypobromous and hypochlorous acids. Water Res. 29, 1203-1206. doi:10.1016/0043-1354(94)00230-5

Kanan, A., Karanfil, T., 2011. Formation of disinfection by-products in indoor swimming pool water: The contribution from filling water natural organic matter and swimmer body fluids. Water Res. 45, 926-932. doi:10.1016/j.watres.2010.09.031

Keuten, M.G. a, Schets, F.M., Schijven, J.F., Verberk, J.Q.J.C., van Dijk, J.C., 2012. Definition and quantification of initial anthropogenic pollutant release in swimming pools. Water Res. 46, 3682-3692. doi:10.1016/j.watres.2012.04.012

Keuten, M.G.A., Peters, M.C.F.M., Daanen, H.A.M., de Kreuk, M.K., Rietveld, L.C., van Dijk, J.C., 2014. Quantification of continual anthropogenic pollutants released in swimming pools. Water Res. 53, 259-70. doi:10.1016/j.watres.2014.01.027

Kim, H., Shim, J., Lee, S., 2002. Formation of disinfection by-products in chlorinated swimming pool water. Chemosphere 46, 123-130. doi:10.1016/S0045-6535(00)00581-6

Kim, H., Weisel, C.P., 1998. Dermal absorption of dichloro- and trichloroacetic acids from chlorinated water. J. Exp. Anal. Env. Epid. 8 (4), 555-575.

Kinani, S., Richard, B., Souissi, Y., Bouchonnet, S., 2012. Analysis or inorganic chloramines in water. Trac-Trends Anal. Chem. 33, 55-67. doi : 10.1016/j.trac.2011.10.006

Kogevinas, M., Villanueva, C.M., Font-Ribera, L., Liviac, D., Bustamante, M., Espinoza, F., Nieuwenhuijsen, M.J.Espinosa, A., Fernandez, P., DeMarini, D.M., Grimalt, J.O., Grummt, T., Marcos, R. Genotoxic effects in swimmers exposed to disinfection by-products in indoor 
swimming pools. Environ. Health Perspect. 118(11), 1531-1537. doi : 10.1289/ehp.1001959

Krasner, S.W., Weinberg, H.S., Richardson, S.D., Pastor, S.J., Chinn, R., Sclimenti, M.J., Onstad, G.D., Thruston, A.D., 2006. Occurrence of a New Generation of Disinfection Byproducts. Environ. Sci. Technol. 40, 7175-7185. doi:10.1021/es060353j

Kuhlich, P., Göstl, R., Teichert, P., Piechotta, C., Nehls, I., 2011. Transformations of polycyclic musks AHTN and HHCB upon disinfection with hypochlorite: two new chlorinated disinfection by-products (CDBP) of AHTN and a possible source for HHCB-lactone. Anal. Bioanal. Chem. 399, 3579-3588. doi:10.1007/s00216-011-4674-3

Lakind, J.S., Richardson, S.D., Blount, B.C., 2010. The good, the bad, and the volatile: Can we have both healthy pools and healthy people? Environ. Sci. Technol. 44, 3205-3210. doi:10.1021/es903241k

Lambropoulou, D.A., Giokas, D.L., Sakkas, V.A., Albanis, T.A., Karayannis, M.I., 2002. Gas chromatographic determination of 2-hydroxy-4-methoxybenzophenone and octyldimethyl-< $\mathrm{i}>\mathrm{p}</ \mathrm{i}>$-aminobenzoic acid sunscreen agents in swimming pool and bathing waters by solid-phase microextraction. J. Chromatogr. A 967, 243-253.

Lee, J., Ha, K.-T., Zoh, K.-D., 2009. Characteristics of trihalomethane (THM) production and associated health risk assessment in swimming pool waters treated with different disinfection methods. Sci. Total Environ. 407, 1990-1997. doi:10.1016/j.scitotenv.2008.11.021

Lee, J., Jun, M.J., Lee, M.H., Lee, M.H., Eom, S.W., Zoh, K.D., 2010. Production of various disinfection byproducts in indoor swimming pool waters treated with different disinfection methods. Int. J. Hyg. Environ. Health 213, 465-474. doi:10.1016/j.ijheh.2010.09.005

Lee, J.H., Na, C., Ramirez, R.L., Olson, T.M., 2006. Cyanogen chloride precursor analysis in chlorinated river water. Environ. Sci. Technol. 40, 1478-1484. doi:10.1021/es051409x

Lévesque, B., Vézina, L., Gauvin, D., Leroux, P., 2015. Investigtaion of air quality problems in an indoor swimming pool : a case study. Ann. Occup. Hyg. 59(8), 1085-1089. doi: 10.1093/annhyg/mev038 
Li, J., Blatchley, E.R., 2007. Volatile disinfection byproduct formation resulting from chlorination of organic - Nitrogen precursors in swimming pools. Environ. Sci. Technol. 41, 6732-6739. doi:10.1021/es070871+

Li, J., Ma, L., Xu, L., 2016. Transformation of benzophenone-type UV filters by chlorine:

Kinetics, products identification and toxicity assessments. J. Hazard. Mater. 311, 263-272. doi:10.1016/j.jhazmat.2016.02.059

Lian, L., Yue, E., Li, J., Blatchley, E.R., 2014. Volatile disinfection byproducts resulting from chlorination of uric acid: Implications for swimming pools. Environ. Sci. Technol. 48, 3210-3217. doi:10.1021/es405402r

Liviac, D., Wagner, E.D., Mitch, W., Altonji, M.J., Plewa, M.J., 2010. Genotoxicity of water concentrates from recreational pools after various disinfection methods. Environ. Sci. Technol. 44, 3527-3532. doi:10.1021/es903593w

Lourencetti, C., Ballester, C., Fernandez, P., Marco, E., Prado, C., Periago, J.F., Grimalt, J.O., 2010. New method for determination of trihalomethanes in exhaled breath : applicaions to swimming pool and bath environments. Anal. Chim. Acta. 662(1), 23-30. doi : 10.1016/j.aca.2009.12.040

Lourencetti, C., Grimalt, J.O., Marco, E., Fernandez, P., Font-Ribera, L., Villanueva, C.M., Kogevinas, M., 2012. Trihalomethanes in chlorine and bromine disinfected swimming pools:air-water distributions and human exposure. Environ. Int. 45, 59-67. doi: 10.1016/j.envint.2012.03.009

Manasfi, T., Storck, V., Ravier, S., Demelas, C., Coulomb, B., Boudenne. J.L., 2015a. Degradation Products of Benzophenone-3 in Chlorinated Seawater Swimming Pools. Environ. Sci. Technol. 49, 9308-9316.

Manasfi, T., De Meo, M., Coulomb, B., Di Giorgio, C., Boudenne, J.L., 2015b. A comparison between freshwater and seawater swimming pools: from disinfection by-products profile to genotoxicity. Full paper \#14. Sixth International Conference on Swimming Pool and Spa, Amsterdam (Netherlands), March 17-20, 
Manasfi, T., De Meo, M., Coulomb, B., Di Giorgio, C., Boudenne, J.L., 2016. Identification of disinfection by-products in freshwatyer and seawater swimming pools and evaluation of genotoxicity. Environ. Int. 88, 94-102. doi : 10.1016/j.envint.2015.12.028

Manasfi, T., De Meo, M., Di Giorgio, C., Coulomb, B., Boudenne, J.-L., 2017a. Assessing the genotoxicity of two commonly occurring byproducts of water disinfection : chloral hydrate and bromate hydral. Mutat. Res. Genet. Toxicol. Environ.Mutagen. 813, 37-44, doi: . 10.1016/j.mrgentox.2016.11.009.

Manasfi, T., Temime-Roussel, B., Coulomb, B., Vassalo, L., Boudenne, J.-L., 2017b. Occurrence of brominated disinfection by-products in the air and water of chlorinated seawater swimming pools. Accepted with minor revisions in the present special issue.

Marco, E., Lourencetti, C., Grimalt, J.O., Gari, M., Fernandez, P., Font-Ribera, L., Villanueva, C.M., Kogevinas, M., 2015. Influence of physical activity in the intake of trihalomethanes in indoor swimming pools. Environ. Res. 140, 292-299. doi : 10.1016/j.envres.2015.04.005

Massin, N., Bohadana, A.B., Wild, P., Hery, M., Toamain, J.P., Hubert, G., 1998. Respiratory symptoms and bronchial responsiveness in lifeguards exposed to nitrogen trichloride in indoor swimming pools. Occup. Environ. Med. 55, 258-263. doi:10.1136/oem.55.4.258

Matsumoto, I., Araki, H., Tsuda, K., Odajima, H., Nishima, S., Higaki, Y., Tanaka, H., Tanaka, M., Shindo, M., 1999. Effects of swimming training on aerobic capacity and exercise induced bronchoconstriction in children with bronchial asthma. Thorax 54, 196-201. doi:10.1136/thx.54.3.196

Melnick, R.L., Nyska, A., Foster, P.M., Roycroft, J.H., Kissling, G.E., 2007. Toxicity and carcinogenicity of the water disinfection byproduct, dibromoacetic acid, in rats and mice. Toxicology 230, 126-136. doi:10.1016/j.tox.2006.11.006

Moser, V.C., Phillips, P.M., Levine, A.B., McDaniel, K.L., Sills, R.C., Jortner, B.S., Butt, M.T., 2004. Neurotoxicity Produced by Dibromoacetic Acid in Drinking Water of Rats. Toxicol. Sci. 79, 112-122. doi:10.1093/toxsci/kfh081

Moser, V.C., Phillips, P.M., McDaniel, K.L., MacPhail, R.C., 1999. Behavioral Evaluation of the 
Neurotoxicity Produced by Dichloroacetic Acid in Rats. Neurotoxicol. Teratol. 21, 719-731. doi:10.1016/S0892-0362(99)00029-X

Muellner, M.G., Wagner, E.D., Mccalla, K., Richardson, S.D., Woo, Y.T., Plewa, M.J., 2007. Haloacetonitriles vs. regulated haloacetic acids: Are nitrogen-containing DBFs more toxic? Environ. Sci. Technol. 41, 645-651. doi:10.1021/es0617441

Na, C., Olson, T.M., 2006. Mechanism and kinetics of cyanogen chloride formation from the chlorination of glycine. Environ. Sci. Technol. 40, 1469-1477. doi:10.1021/es0512273

Nakajima, M., Kawakami, T., Niino, T., Takahashi, Y., Onodera, S., 2009. Aquatic Fate of Sunscreen Agents Octyl-4-methoxycinnamate and Octyl-4-dimethylaminobenzoate in Model Swimming Pools and the Mutagenic Assays of Their Chlorination Byproducts. J. Heal. Sci. 55, 363-372. doi:10.1248/jhs.55.363

Negreira, N., Canosa, P., Rodríguez, I., Ramil, M., Rubí, E., Cela, R., 2008. Study of some UV filters stability in chlorinated water and identification of halogenated by-products by gas chromatography-mass spectrometry. J. Chromatogr. A 1178, 206-214. doi:10.1016/j.chroma.2007.11.057

Nelemans, P.J., Rampen, F.H., Groenendal, H., Kiemeney, L.A., Ruiter, D.J., Verbeek, A.L., 1994. Swimming and the risk of cutaneous melanoma. Melanoma Res. 4, 281-6.

Nickmilder, M., Bernard, A., 2006. Ecological association between childhood asthma and availability of indoor chlorinated swimming pools in Europe. Occup. Environ. Med. 64, 3746. doi:10.1136/oem.2005.025452

Nieuwenhuijsen, M.J., Toledano, M.B., Eaton, N.E., Fawell, J., Elliott, P., 2000. Chlorination disinfection byproducts in water and their association with adverse reproductive outcomes: a review. Occup. Environ. Med. 57, 73-85. doi:10.1136/oem.57.2.73

Nieuwenhuijsen, M.J., Smith, R., Golfinopoulos, S., Best, N., Bennett, J., Aggazzotti, G., Righi, E., Fantuzzi, G., Bucchini, L., Cordier, S., Villanueva, C.M., Moreno, V., La Vecchia, C., Bosetti, C., Vartiainen, T., Rautiu, R., Toledano, M., Iszatt, N., Grazuleviciene, R., Kogevinas, M., 2009. Health impacts of long-term exposure to disinfection by-products in 
drinking water in Europe: HIWATE. J. Water Health 7, 185-207. doi:10.2166/wh.2009.073

Nystad, W., Njå, F., Magnus, P., Nafstad, P., 2007. Baby swimming increases the risk of recurrent respiratory tract infections and otitis media. Acta Paediatr. 92, 905-909. doi:10.1111/j.1651-2227.2003.tb00622.x

Panyakapo, M., Soontornchai, S., Paopuree, P., 2008. Cancer risk assessment from exposure to trihalomethanes in tap water and swimming pool water. J. Environ. Sci. 20 (3), 372-378.

Parrat, J., Donzé, G., Iseli, C., Perret, D., Tomicic, C., Schenk, O., 2012. Assessment of Occupational and Public Exposure to Trichloramine in Swiss Indoor Swimming Pools: A Proposal for an Occupational Exposure Limit. Ann. Occup. Hyg. 56(3), 264-277. doi: 10.1093/annhyg/mer125

Plewa, M.J., Kargalioglu, Y., Vankerk, D., Minear, R. a., Wagner, E.D., 2002. Mammalian cell cytotoxicity and genotoxicity analysis of drinking water disinfection by-products. Environ. Mol. Mutagen. 40, 134-142. doi:10.1002/em.10092

Plewa, M.J., Wagner, E.D., Muellner, M.G., Hsu, K.-M., Richardson, S.D., 2008. Comparative mammalian cell toxicity of N-DBPs and C-DBPs. Disinfection By-Products in Drinking Water, ACS Symposium Series. American Chemical Society, Washington, DC. doi:10.1021/bk-2008-0995

Plewa, M.J., Simmons, J.E., Richardson, S.D., Wagner, E.D., 2010. Mammalian cell cytotoxicity and genotoxicity of the haloacetic acids, a major class of drinking water disinfection byproducts. Environ. Mol. Mutagen. 51, 871-8. doi:10.1002/em.20585

Rahman, M.B., Driscoll, T., Cowie, C., Armstrong, B.K., 2010. Disinfection by-products in drinking water and colorectal cancer: a meta-analysis. Int. J. Epidemiol. 39, 733-45. doi:10.1093/ije/dyp371

Ramos, S., Homem, V., Alves, A., Santos, L., 2015. Advances in analytical methods and occurrence of organic UV-filters in the environment - A review. Sci. Total Environ. 526, 278-311. doi:10.1016/j.scitotenv.2015.04.055 
Richardson, M.L., Bowron, J.M., 1985. The fate of pharmaceutical chemicals in the aquatic environment. J. Pharm. Pharmacol. 37, 1-12. doi:10.1111/j.2042-7158.1985.tb04922.x

Richardson, S., Plewa, M., Wagner, E., Schoeny, R., Demarini, D., 2007. Occurrence, genotoxicity, and carcinogenicity of regulated and emerging disinfection by-products in drinking water: A review and roadmap for research. Mutat. Res. Mutat. Res. 636, 178-242. doi:10.1016/j.mrrev.2007.09.001

Richardson, S.D., DeMarini, D.M., Kogevinas, M., Fernandez, P., Marco, E., Lourencetti, C., Ballesté, C., Heederik, D., Meliefste, K., McKague, A.B., Marcos, R., Font-Ribera, L., Grimalt, J.O., Villanueva, C.M., 2010. What's in the Pool? A Comprehensive Identification of Disinfection By-products and Assessment of Mutagenicity of Chlorinated and Brominated Swimming Pool Water. Environ. Health Perspect. 118, 1523-1530. doi:10.1289/ehp.1001965

Richardson, S.D., Kimura, S.Y., 2016. Water Analysis: Emerging Contaminants and Current Issues. Anal. Chem. 88, 546-82. doi:10.1021/acs.analchem.5b04493

Richardson, S.D., Postigo, C., 2011. Drinking Water Disinfection By-products. Springer Berlin Heidelberg, pp. 93-137. doi:10.1007/698_2011_125

Righi, E., Fantuzzi, G., Predieri, G., Aggazzotti, G., 2014. Brmate, chlorite, chlorate, haloacetic acids, and trihalomethanes in indoor swimming pool waters in Italy. Microchem. J., 133,2329. doi: 10.1016/j.microc.2013.11.007

Rook, J., 1974. Formation of haloforms during chlorination of natural waters. Water Treat. Exam.

Rosimini, C., 2003. Benefits of Swim Training for Children and Adolescents with Asthma. J. Am. Acad. Nurse Pract. 15, 247-252. doi:10.1111/j.1745-7599.2003.tb00394.x

Sá, C.S.A., Boaventura, R.A.R., Pereira, I.B., 2012. Analysis of haloacetic acids in water and air (aerosols) from indoor swimming pools using HS-SPME/GC/ECD. http://dx.doi.org/10.1080/10934529.2012.640246.

Sakkas, V.., Giokas, D.., Lambropoulou, D.., Albanis, T.., 2003. Aqueous photolysis of the sunscreen agent octyl-dimethyl-p-aminobenzoic acid. J. Chromatogr. A 1016, 211-222. 
doi:10.1016/S0021-9673(03)01331-1

Santos, A.J.M., Miranda, M.S., Esteves da Silva, J.C.G., 2012. The degradation products of UV filters in aqueous and chlorinated aqueous solutions. Water Res. 46, 3167-3176. doi:10.1016/j.watres.2012.03.057

Shen, R., Andrews, S.A., 2011. Demonstration of 20 pharmaceuticals and personal care products (PPCPs) as nitrosamine precursors during chloramine disinfection. Water Res. 45, 944-952. doi:10.1016/j.watres.2010.09.036

Silvia Díaz-Cruz, M., Llorca, M., Barceló, D., Barceló, D., 2008. Organic UV filters and their photodegradates, metabolites and disinfection by-products in the aquatic environment. TrAC Trends Anal. Chem. 27, 873-887. doi:10.1016/j.trac.2008.08.012

Simard, S., Tardif, R., Rodriguez, M.J., 2013. Variability of chlorination by-product occurrence in water of indoor and outdoor swimming pools. Water Res. 47, 1763-1772. doi:10.1016/j.watres.2012.12.024

Spiliotopoulou, A., Hansen, K.M.S., Andersen, H.R., 2015. Secondary formation of disinfection by-products by UV treatment of swimming ool water. Sci. Total Environ. 520, 96-105.

Tardif, R., Catto, C., Haddad, S., Simard, S., Rodriguez, M., 2016. Assessment of air and water contamination by disinfection by-products at 41 indoor swimming pools. Environ. Res. 148, 411-420. doi : 10.1016/j.envres.2016.04.011

Tardiff, R.G., Carson, M.L., Ginevan, M.E., 2006. Updated weight of evidence for an association between adverse reproductive and developmental effects and exposure to disinfection byproducts. Regul. Toxicol. Pharmacol. 45, 185-205. doi:10.1016/j.yrtph.2006.03.001

Teo, T.L.L., Coleman, H.M., Khan, S.J., 2016. Occurrence and daily variability of pharmaceuticals and personal care products in swimming pools. Environ. Sci. Pollut. Res. 23, 6972-6981. doi:10.1007/s11356-015-5967-4

Teo, T.L.L., Coleman, H.M., Khan, S.J., 2015. Chemical contaminants in swimming pools: Occurrence, implications and control. Environ. Int. doi:10.1016/j.envint.2014.11.012 
Terasaki, M., Makino, M., 2008. Determination of chlorinated by-products of parabens in swimming pool water. Int. J. Environ. Anal. Chem. 88, 911-922. doi:10.1080/03067310802272663

Ternes, T.A., Joss, A., Siegrist, H., 2004. Peer Reviewed: Scrutinizing Pharmaceuticals and Personal Care Products in Wastewater Treatment. Environ. Sci. Technol. 38, 392A-399A. doi:10.1021/es040639t

Urbansky, E.T., Magnuson, M.L., 2002. Analyzing Drinking Water for Disinfection Byproducts. Anal. Chem. 74, 260 A-267 A. doi:10.1021/ac022009k

Valle-Sistac, J., Molins-Delgado, D., Díaz, M., Ibáñez, L., Barceló, D., Silvia Díaz-Cruz, M., 2016. Determination of parabens and benzophenone-type UV filters in human placenta: First description of the existence of benzyl paraben and benzophenone-4. Environ. Int. 88, 243249. doi:10.1016/j.envint.2015.12.034

Villanueva, C.M., Cantor, K.P., Cordier, S., Jaakkola, J.J.K., King, W.D., Lynch, C.F., Porru, S., Kogevinas, M., 2004. Disinfection Byproducts and Bladder Cancer. Epidemiology 15, 357367. doi:10.1097/01.ede.0000121380.02594.fc

Villanueva, C.M., Cantor, K.P., Grimalt, J.O., Malats, N., Silverman, D., Tardon, A., GarciaClosas, R., Serra, C., Carrato, A., Castaño-Vinyals, G., Marcos, R., Rothman, N., Real, F.X., Dosemeci, M., Kogevinas, M., 2007. Bladder cancer and exposure to water disinfection byproducts through ingestion, bathing, showering, and swimming in pools. Am. J. Epidemiol. 165, 148-156. doi:10.1093/aje/kwj364

Villanueva, C.M., Cordier, S., Font-Ribera, L., Salas, L.A., Levallois, P., 2015. Overview of Disinfection By-products and Associated Health Effects. Curr. Environ. Heal. reports 2, 107-115. doi:10.1007/s40572-014-0032-X

Walse, S.S., Mitch, W.A., 2008. Nitrosamine carcinogens also swim in chlorinated pools. Environ. Sci. Technol. 42, 1032-1037. doi:10.1021/es702301p

Wang, W., Qian, Y., Boyd, J.M., Wu, M., Hrudey, S.E., Li, X.F., 2013. Halobenzoquinones in swimming pool waters and their formation from personal care products. Environ. Sci. 
Technol. 47, 3275-3282. doi:10.1021/es304938x

Wang, J.J., Liu, X., Ng, T.W., Xiao, J.W., Chow, A.T., Wong, P.K., 2013. Disinfection byproduct formation from chlorination of pure bacterial cells and pipeline biofilms. Water Res. 47, 2701-2709. doi : 10.1016/j.watres.2013.02.038

Wang, X., M I, G.L., Zhang, X., Yang, H., Xie, Y., 2014. Haloacetic acids in swimming pool and spa water in the United States and China. Front. Environ. Sci. Eng. 8, 820-824. doi:10.1007/s11783-014-0712-7

Weaver, W.A., Li, J., Wen, Y., Johnston, J., Blatchley, M.R., Blatchley III, E.R., 2009. Volatile disinfection by-product analysis from chlorinated indoor swimming pools. Water Res. 43, 3308-3318. doi:10.1016/j.watres.2009.04.035

Weinberg, H.S., Krasner, S.W., Richardson, S.D., Thruston, a D., 2002. EPA The Occurrence of Disinfection By-Products (DBPs) of Health Concern in Drinking Water: Results of a Nationwide DBP Occurrence Study 462p. doi:EPA/600/R-02/068

Weisel, C.P., Richardson, S.D., Nemery, B., Aggazzotti, G., Baraldi, E., Blatchley, E.R., Blount, B.C., Carlsen, K.-H., Eggleston, P.A., Frimmel, F.H., Goodman, M., Gordon, G., Grinshpun, S.A., Heederik, D., Kogevinas, M., LaKind, J.S., Nieuwenhuijsen, M.J., Piper, F.C., Sattar, S.A., 2009. Childhood Asthma and Environmental Exposures at Swimming Pools: State of the Science and Research Recommendations. Environ. Health Perspect. 117, 500-507. doi:10.1289/ehp.11513

Weng, S., Blatchley III, E.R., 2011. Disinfection by-product dynamics in a chlorinated indoor swimming pool under conditions of heavy use : National swimming comptetition. Water Res. 45(16), 5241-5248. doi : 10.1016/j.watres.2011.07.027

Weng, S., Li, J., Blatchley III, E.R., 2012. Effects of UV 254 irradiation on residual chlorine and DBPs in chlorination of model organic-N precursors in swimming pools. Water Res. 46, 2674-2682. doi:10.1016/j.watres.2012.02.017

Weng, S., Sun, P., Ben, W., Huang, C., Lee, L.T., Iii, E.R.B., 2014. The Presence of Pharmaceuticals and Personal Care Products in Swimming Pools. 
Westerlund, J., Graff, P., Bryngelsson, I.L., Westberg, H., Eriksson, K., Löfstedt, H., 2015. Occupational Exposure to Trichloramine and Trihalomethanes in Swedish Indoor Swimming Pools: Evaluation of Personal and Stationary Monitoring. Ann. Occup. Hyg. 59(8), 1074-1084. doi : :10.1093/annhyg/mev045

WHO, 2006. Guidelines for Safe Recreational Waters. Volume 2. Swimming Pools and Similar Recreational-water Environments. WHO, Geneve, p. 118.

Xu, X., Weisel, C.P., 2005. Dermal uptake of chloroform and haloketones during bathing. 15(4), 289-296. J. Expo. Anal. Env. Epid. doi : 10.1038/sj.jea.7500404

Yang, X., Shang, C. 2005. Quantification of aqueous cyanogen chloride and cyanogen bromide in environmental samples by MIMS. Water Res. 39, 1709-1718. doi:10.1016/j.watres.2005.01.030

Yang, Y., Komaki, Y., Kimura, S.Y., Hu, H., Wagner, E.D., Marinas, B.J., Plewa, M.J., 2014. Toxic Impact of Bromide and Iodide on Drinking Water Disinfected with Chlorine or Chloramines. Environ. Sci. Technol. 48, 12362-12369.

Yeh, R.Y.L., Farré, M.J., Stalter, D., Tang, J.Y.M., Molendijk, J., Escher, B.I., 2014. Bioanalytical and chemical evaluation of disinfection by-products in swimming pool water. Water Res. 59, 172-184. doi:10.1016/j.watres.2014.04.002

Zwiener, C., Richardson, S.D., De Marini, D.M., Grummt, T., Glauner, T., Frimmel, F.H., 2007. Drowning in Disinfection Byproducts? Assessing Swimming Pool Water. Environ. Sci. Technol. 41, 363-372. doi:10.1021/es062367v 